\title{
Astroglial Connexin 43 Hemichannels Modulate Olfactory Bulb Slow Oscillations
}

\author{
Lisa Roux, ${ }^{1,2,3}$ Antoine Madar, ${ }^{1,2,3}$ Marie Masako Lacroix, ${ }^{4}$ Chenju Yi, ${ }^{1,2,3}$ Karim Benchenane, ${ }^{4 \star}$ \\ and Christian Giaume ${ }^{1,2,3 *}$ \\ ${ }^{1}$ Center for Interdisciplinary Research in Biology, Collège de France/Centre National de la Recherche Scientifique, Unité Mixte de Recherche 7241, Institut \\ National de la Santé et de la Recherche Médicale U1050, 75231 Paris Cedex 05, France, ${ }^{2}$ University Pierre et Marie Curie, 75005 Paris, France, ${ }^{3}$ MemoLife \\ Laboratory of Excellence and Paris Science Lettre Research University, 75005 Paris, France, ${ }^{4}$ Memory Oscillations and Brain States Team, Laboratory of \\ Neurobiology, Brain Plasticity Unit, Unité Mixte de Recherche 8249, CNRS, Ecole Supérieure de Physique et de Chimie Industrielles de la Ville de Paris - \\ ParisTech, 75005 Paris, France
}

An emergent concept in neurosciences consists in considering brain functions as the product of dynamic interactions between neurons and glial cells, particularly astrocytes. Although the role played by astrocytes in synaptic transmission and plasticity is now largely documented, their contribution to neuronal network activity is only beginning to be appreciated. In mouse olfactory bulb slices, we observed that the membrane potential of mitral cells oscillates between UP and DOWN states at a low frequency ( $<1 \mathrm{~Hz})$. Such slow oscillations are correlated with glomerular local field potentials, indicating spontaneous local network activity. Using a combination of genetic and pharmacological tools, we showed that the activity of astroglial connexin 43 hemichannels, opened in an activity-dependent manner, increases UP state amplitude and impacts mitral cell firing rate. This effect requires functional adenosine A1 receptors, in line with the observation that ATP is released via connexin 43 hemichannels. These results highlight a new mechanism of neuroglial interaction in the olfactory bulb, where astrocyte connexin hemichannels are both targets and modulators of neuronal circuit function.

Key words: astrocyte; hemichannel; mitral cells; olfactory glomeruli; UP state; DOWN state

\section{Significance Statement}

An emergent concept in neuroscience consists in considering brain function as the product of dynamic interactions between neurons and glial cells, particularly astrocytes. A typical feature of astrocytes is their high expression level of connexins, the molecular constituents of gap junction channels and hemichannels. Although hemichannels represent a powerful medium for intercellular communication between astrocytes and neurons, their function in physiological conditions remains largely unexplored. Our results show that in the olfactory bulb, connexin 43 hemichannel function is promoted by neuronal activity and, in turn, modulates neuronal network slow oscillations. This novel mechanism of neuroglial interaction could influence olfactory information processing by directly impacting the output of the olfactory bulb.

\section{Introduction}

Over the last two decades, emerging concepts that integrate glial cells, and in particular astrocytes, in the regulation of neuronal

\footnotetext{
Received March 5, 2015; revised Aug. 24, 2015; accepted Sept. 27, 2015.

Author contributions: L.R., K.B., and C.G. designed research; L.R., A.M., M.M.L., and C.Y. performed research; K.B. and C.G. contributed unpublished reagents/analytic tools; L.R., A.M., M.M.L., C.Y., and K.B. analyzed data; L.R. and C.G. wrote the paper.

This work was supported by the Neuropôle de Recherche Francilien Collège de France, and Agence Nationale pour la Recherche Grants AstroGlo 06-NEURO-004-01 and Astrosleep 12-BSV4-0013-01. We thank Drs. A. Koulakoff, N.

Rouach, 0. Chever, X. Liu, and T. Gallopin for discussions and technical support, P. Ezan for technical help, and Profs. K. Willecke and $M$. Theis for providing knock-out mice.

The authors declare no competing financial interests.

*K.B. and C.G. contributed equally to this work.

Correspondence should be addressed to Christian Giaume, Collège de France, 11 place Marcelin Berthelot, 75231

Paris Cedex 05, France. E-mail: christian.giaume@college-de-france.fr.
}

activity and metabolism have considerably improved our understanding of brain functions (Barres, 2008; Nedergaard and Verkhratsky, 2012; Pellerin and Magistretti, 2012; Araque et al., 2014). However, although the role played by astrocytes in the modulation of synaptic transmission and plasticity is well documented, their contribution to network activity is only beginning to be considered both in vitro (Angulo et al., 2004; Poskanzer and Yuste, 2011; Lee et al., 2014) and in vivo (Amzica et al., 2002; Fellin et al., 2009; Halassa et al., 2009; Lee et al., 2014). Most of these studies point out the role played by astrocyte calciumdependent vesicular release (Bezzi et al., 2004; Pascual et al., 2005; 
Jourdain et al., 2007; Bergersen et al., 2012; Lee et al., 2014), a mechanism that is still controversial (Fiacco et al., 2007; Petravicz et al., 2008; Agulhon et al., 2010; Hamilton and Attwell, 2010; Li et al., 2013; Fujita et al., 2014).

Yet, astrocytes could contribute to neuronal network activity through other pathways. A typical feature of astrocytes is their high level of connexin ( $\mathrm{Cx})$ expression $(\mathrm{Cx} 43$ and $\mathrm{Cx} 30)$, the molecular basis for gap junction channel and hemichannel (HC) functions (Giaume et al., 2010). Both of these channels are permeable to numerous neuroactive compounds (Bennett et al., 2003; Giaume et al., 2013). Whereas the role of astroglial gap junctions (Wallraff et al., 2006; Rouach et al., 2008; Lutz et al., 2009; Pannasch et al., 2011) and nonchannel functions of Cx30 (Pannasch et al., 2014) have been studied extensively in the hippocampus, the role of $\mathrm{Cx}$-formed HCs in physiological conditions is only beginning to be appreciated (Stehberg et al., 2012; Torres et al., 2012; Chever et al., 2014). Therefore, we asked whether $\mathrm{Cx} \mathrm{HC}$ function in astrocytes impacts neuronal network activity.

As a model, we used the mouse olfactory bulb (OB), where intricate neuroglial interactions have been described previously (De Saint Jan and Westbrook, 2005; Gurden et al., 2006; Roux et al., 2011). In addition, the OB presents the advantage of exhibiting strong network activity in acute slice preparations, as reflected by coordinated long-lasting depolarizations in mitral cells (MCs) belonging to the same glomerulus (Carlson et al., 2000; Schoppa and Westbrook, 2001, 2002; Christie et al., 2005; Christie and Westbrook, 2006; De Saint Jan et al., 2009). The involvement of intrinsic membrane properties (Heyward et al., 2001) and/or circuit interactions as well as the contribution of neuroglial interactions in these network activity patterns are still unclear.

Our results uncover a novel mechanism of neuroglial interaction in the $\mathrm{OB}$, where $\mathrm{Cx} 43$ hemichannel function in astrocytes is promoted by neuronal activity and, in turn, modulates neuronal network function via a purinergic pathway. This mechanism could influence olfactory information processing by directly impacting the output of the $\mathrm{OB}$.

\section{Materials and Methods}

All experiments were performed according to the European Community Council Directives of January first 2013 (2010/63/EU) and followed Institut National de la Santé et de la Recherche Médicale guidelines for the ethical treatment of animals. They were also in accordance with institutional (CNRS Comité Operationnel pour l'Ethique dans les Sciences de la Vie) and international (NIH guidelines) standards and legal regulations (Ministère de l'Agriculture et de la Pêche) regarding the use and care of animals. All efforts were made to minimize the number of animals used and their suffering.

\section{Animals}

C57BL/6 mice (Charles River Laboratories) were used as wild-type (WT) mice. To assess astroglial connexin functions, we used knock-out mice, including $C \times 30^{-/-}$(Сx30 KO; Teubner et al., 2003), Cx43 $3^{f l f l}:$ GFAP-cre (Cx43 KO), a conditional knock-out of $\mathrm{Cx} 43$ in astrocytes (Theis et al., 2003), and the double knock-out (dKO) $C \times 30^{-1-} C \times 43^{f l / f l}:$ GFAP-cre (Wallraff et al., 2006). Both male and female mice were used in this study.

\section{Drugs and peptides}

The following drugs were used in this study: tetrodotoxin citrate (TTX; $0.5 \mu \mathrm{M}$; Tocris Biosciences), 4-hydroxyquinoline-2-carboxylic acid (kynurenic acid; $2 \mathrm{~mm}$; Tocris Biosciences), carbenoxolone (CBX; 100 $\mu \mathrm{M}$; Sigma), 4-(2-(7-amino-2-(furan-2-yl)-[1,2,4] triazolo[1,5-a][1,3,5] triazin-5-ylamino)ethyl)phenol (ZM 241385; $10 \mathrm{nM}$; Tocris Biosciences), 8-cyclopentyl-1,3-dipropylxanthine (DPCPX; $1 \mu \mathrm{m}$; Tocris Biosciences), the mimetic peptide Gap26 (amino acid sequence VCYDKSFPISHVR; purity, $>95 \% ; 300 \mu \mathrm{g} / \mathrm{ml}$; Thermo Fisher Scientific; Chaytor et al., 1997), and a scrambled peptide containing the same amino acids as the Gap26 (amino acid sequence PSFDSRHCIVKYV; purity, >95\%; 300 $\mu \mathrm{g} / \mathrm{ml}$, Thermo Fisher Scientific). To avoid peptide degradation, peptides were diluted in oxygenated ACSF 2 min before application on the slices. To test the impact of $\mathrm{Cx} 43$ hemichannel function, analysis was performed within the first 10-15 min of recording after peptide exposure, because it has been reported that Gap26 has an effect on gap junction communication after 30 min exposure (Desplantez et al., 2012).

\section{Tissue preparation for electrophysiological recordings}

As described previously (Roux et al., 2011), mice [postnatal day 14 (P14)-P25] were killed by decapitation, and the olfactory bulbs were rapidly dissected in ice-cold oxygenated $\left(95 \% \mathrm{O}_{2}-5 \% \mathrm{CO}_{2}\right)$ solution containing the following (in mM): $83 \mathrm{NaCl}, 26.2 \mathrm{NaHCO} 3,1 \mathrm{NaH}_{2} \mathrm{PO}_{4}$, $2.5 \mathrm{KCl}, 3.3 \mathrm{MgSO}_{4} 0.5 \mathrm{CaCl}$, 70 sucrose, and $22 \mathrm{D}$-glucose, $\mathrm{pH} 7.3$ (osmolarity, $315 \mathrm{mOsm}$ ). Horizontal slices (250-350 $\mu \mathrm{m}$ ) were cut using a vibratome (Microm HM 650V) in the same solution, incubated for $30-40 \mathrm{~min}$ at $34^{\circ} \mathrm{C}$ in the standard extracellular solution (see Electrophysiological recordings section below) in which $10 \mathrm{~mm}$ of pyruvate was added, and stored at room temperature until use (up to $5 \mathrm{~h}$ after decapitation).

\section{Electrophysiological recordings}

Slices were placed in a submerged recording chamber mounted on an upright microscope (Zeiss Axioskop FS) equipped for infrared differential interference contrast (DIC) microscopy and epifluorescence. They were perfused continuously with an oxygenated extracellular solution (ACSF) containing (in $\mathrm{mm}$ ) $124 \mathrm{NaCl}, 26 \mathrm{NaHCO} 3,3 \mathrm{KCl}, 1.25$ $\mathrm{NaH}_{2} \mathrm{PO}_{4}, 1.3 \mathrm{MgCl} 2,2 \mathrm{CaCl} 2$, and 20 D-glucose, pH 7.4 (room temperature) at a rate of $2 \mathrm{ml} / \mathrm{min}$. Patch-clamp recordings were performed with 3-7 M $\Omega$ glass electrodes filled with (in $\mathrm{mm}$ ) $105 \mathrm{~K}$-gluconate, 30 $\mathrm{KCl}, 10$ HEPES, 10 phosphocreatine, 4 ATP-Mg, 0.3 GTPTris, and 0.3 EGTA, pH 7.4 (290 mOsm) for current-clamp recordings, or 107.5 Csgluconate, $20 \mathrm{HEPES}, 8 \mathrm{Na}$-gluconate, 8 tetraethylammonium (TEA)-Cl, 4 ATP-Mg, $0.3 \mathrm{Na}_{3}$-GTP, 0.2 EGTA, 5 QX-314, pH 7.2 (280 mOsm) for voltage-clamp recordings. Sulforhodamine B ( $\mathrm{SrB} ; 1 \mathrm{mg} / \mathrm{ml}$; Invitrogen) was systematically added to this internal solution to verify cell integrity after recording. Whole-cell membrane voltages were recorded with a MultiClamp 700B amplifier (Molecular Devices), sampled with a Digidata $1322 \mathrm{~A}$ Interface, and recordings ( $10 \mathrm{kHz}$ sampling, $2 \mathrm{kHz}$ filtering) were performed with pClamp9 software (Molecular Devices). Series resistances were compensated at $80 \%$. Input resistance was measured in voltage-clamp mode by applying hyperpolarizing voltage pulses $(10 \mathrm{mV}$, $150 \mathrm{~ms}$ ) from a holding potential of $-60 \mathrm{mV}$ for MCs. Unless indicated, all recorded MCs were maintained by steady current injection at the same DOWN state membrane potential $(-60 \mathrm{mV})$ to minimize the variability related to this parameter. Mitral cell recordings included in this work presented $29 \pm 11 \mathrm{M} \Omega$ access resistance $\left(R_{\mathrm{a}}\right)$. We did not observe any significant correlation between access resistance and UP state amplitude. Local field potential (LFP) recordings were performed with $0.5-1 \mathrm{M} \Omega$ glass pipettes filled with extracellular solution.

\section{Data analysis}

Analysis was performed using Matlab software (MathWorks).

Cross-correlograms. Cross-correlogram analyses were performed with custom-written, MATLAB-based programs. A significant value for the correlation coefficient $(r)$ at the lag zero indicates that the two signals do not evolve independently. We defined the delay between the two signals as the lag corresponding to the time delay that optimizes the correlation between them. To study the temporal relationship between MC membrane potential fluctuations and LFP signals recorded either in the glomerulus affiliated with the MC or in neighboring glomeruli, spikes were removed from the MC signal, and cross-correlogram analysis was performed on recordings filtered in the $0.05-0.6 \mathrm{~Hz}$ frequency band.

UP state detection. The strategy developed by Seamari et al. (2007) for characterizing UP and DOWN states is based on a method used in financial data analysis: crossover of moving averages. Periods where a signal keeps its tendency to increase or decrease (trending periods) can be 
tracked with fitted exponential moving averages (EMAs), whereas changes in this trending behavior (trend reversal) are detected by crossing over two EMAs with different window sizes. The windows sizes were chosen to detect events occurring between 0.05 and $2 \mathrm{~Hz}$. Accordingly, classical Fourier analysis reveals a peak at those frequencies. The crossing points of the two EMAs are good approximations of the transitions between UP and DOWN states (i.e., of both UP initiations and terminations). Similar results were obtained with a more classical method based on the decomposition of the histogram of the membrane potential into a mixture of two Gaussians.

\section{Ethidium bromide uptake assays}

$\mathrm{HC}$ activity was assessed by ethidium bromide (EtBr; 314Da) uptake assays (Giaume et al., 2012) in 300- $\mu \mathrm{m}$-thick acute OB slices prepared as described above for electrophysiological recordings. Briefly, slices were first preincubated for $15 \mathrm{~min}$ in different submerged chambers containing oxygenated $\left(95 \% \mathrm{O}_{2}\right.$ and $\left.5 \% \mathrm{CO}_{2}, \mathrm{pH} 7.4\right)$ ACSF and different pharmacological compounds. $\mathrm{EtBr}(4 \mu \mathrm{M})$ was then directly added in the chamber. Repetitive gentle pipetting allowed homogenization of the solution. This compound is membrane impermeable but can transit through large-pore channels before binding to the cell's DNA when it becomes more fluorescent. After $10 \mathrm{~min}$ exposure to $\mathrm{EtBr}$, slices were washed (two times for $5 \mathrm{~min}$ each) in normal ACSF, fixed for $3 \mathrm{~h}$ in $4 \%$ PFA in PBS, and processed for anti-GFAP immunostaining and Nissl staining (see Immunostaining section below). Sections were mounted in Fluoromount and imaged with a confocal laser-scanning microscope equipped with a $40 \times$ objective and three lasers (argon, $488 \mathrm{~nm}$; helium/ neon, $543 \mathrm{~nm}$; helium/neon, $633 \mathrm{~nm}$ ). Images were taken $25 \mu \mathrm{m}$ below the slice surface in each condition. Pictures were analyzed with MBF ImageJ software. By means of Nissl and GFAP staining, regions of interest (ROIs) were defined corresponding to astrocyte nuclei located in the glomerular layer. The mean EtBr fluorescence intensity was measured in each ROI, after background removal. Background was evaluated on at least five regions devoid of cell bodies for each analyzed frame. Results for the different conditions were normalized by the mean EtBr signal obtained in the corresponding WT control condition.

\section{Immunostaining (after EtBr uptake assays)}

Antibodies. Mouse monoclonal anti-GFAP antibodies (1:500; Sigma, clone GA-5) were used as primary antibodies. Goat anti-mouse Igs conjugated to Alexa fluor dyes (1:4000; Invitrogen) were used as secondary antibodies.

Protocols. Acute OB slices ( $300 \mu \mathrm{m}$ thick) were prepared as for electrophysiology and fixed in $4 \%$ PFA overnight at $4^{\circ} \mathrm{C}$. Alternatively, slices were fixed during $3 \mathrm{~h}$ following $\mathrm{EtBr}$ assays (see above). After two PBS washes (30 min each), slices were permeabilized with PBS containing $0.2 \%$ gelatin and $1 \%$ Triton $\mathrm{X}-100$ for $1 \mathrm{~h}$ at room temperature and incubated overnight at $4^{\circ} \mathrm{C}$ with mouse anti-GFAP antibodies diluted in PBS containing $0.2 \%$ gelatin and $0.25 \%$ Triton X-100. After two washes (30 min each), sections were incubated for $2 \mathrm{~h}$ at room temperature with secondary antibodies. After two washes (20 min each), Nissl counterstaining was performed by incubating the sections during $20 \mathrm{~min}$ in Neurotrace reagent (1:100; Invitrogen) diluted in PBS. After three washes (10 min each), sections were mounted in Fluoromount and imaged with a confocal laser-scanning microscope, equipped with a $40 \times$ objective and three lasers (argon, $488 \mathrm{~nm}$; helium/neon, $543 \mathrm{~nm}$; helium/neon, $633 \mathrm{~nm})$.

\section{ATP dosage by bioluminescence assays}

Extracellular levels of ATP were determined from OB acute slices prepared as described above ( $n=2$ slices/well/condition) incubated in $1 \mathrm{ml}$ of oxygenated ACSF containing Gap26 $(300 \mu \mathrm{g} / \mathrm{ml})$ or not. After equilibration, slices were treated for $30 \mathrm{~min}$ in presence of the ectonucleotidase inhibitor ARL 67156 trisodium salt (6- $N, N$-Diethyl-D- $\beta$, $\gamma$-dibromomethylene ATP trisodium salt; Tocris Bioscience) to inhibit ATP hydrolysis. Then, samples of extracellular medium were collected, and extracellular ATP was directly measured using a bioluminescent ATP assay kit (PerkinElmer) as described previously (Cotrina et al., 1998). Luminescence was measured using a luminometer (Berthold Technologies) according to the manufacturer's instructions. The extracellular ATP was normalized to the protein content determined from pooled OB slices by BCA kit (Thermo Scientific).

\section{Statistics}

For each data group, results are expressed as mean \pm SEM, and $n$ refers to the number of independent experiments. Comparisons are considered significant at $p<0.05, p<0.01$, and $p<0.001$, and $p$ values for correlation coefficients were obtained via the corrcoef function (MathWorks).

\section{Results}

\section{Mitral cell membrane potential bimodality}

Whole-cell recordings from MCs were performed in mouse acute OB slices (P14-P25). A fluorescent molecule, sulforhodamine B $(\mathrm{SrB})$, was systematically included in the patch-clamp pipette solution to assess cell morphology and integrity (Figs. $1 A_{1}, B_{1}$, $3 D)$. We monitored MCs at their resting membrane potential in the current-clamp configuration and observed spontaneous alternations between depolarized states often associated with spikes and silent hyperpolarized states $\left(\right.$ Fig. $\left.1 A_{2}, C\right)$ resulting in a bimodal distribution (Fig. $1 A_{3}$ ). Such slow alternations between two distinct membrane potentials are reminiscent of neocortical neuron oscillations typically observed during slow wave sleep and anesthesia (Steriade et al., 1993), as well as during quiet wakefulness (Crochet and Petersen, 2006). By analogy, we defined the activated state as the UP state and the hyperpolarized state as the DOWN state in the rest of our study. Only MCs with clear UP and DOWN states and allowing long $(>10 \mathrm{~min})$ stable recordings were included in the following analysis (45 of 61). Detected UP state frequency was $0.19 \pm 0.01 \mathrm{~Hz}(n=45)$. The firing rate monitored during UP states was $11.47 \pm 1.5 \mathrm{~Hz}$, whereas it reached only $0.16 \pm 0.04 \mathrm{~Hz}$ during DOWN states. UP and DOWN state membrane potentials corresponded to $-48.5 \pm 0.8$ $\mathrm{mV}$ and $-52.9 \pm 0.8 \mathrm{mV}$, respectively, with a potential difference between those two states (referred to as the UP state amplitude) of $4.4 \pm 0.3 \mathrm{mV}$. The transitions between these two voltage levels lasted (337.5 $\pm 18.3 \mathrm{~ms}$ for DOWN to UP states and 518.2 \pm 45.5 ms for UP to DOWN states). Short buildups of EPSPs could be observed at UP state initiation (Fig. 1C). UP and DOWN state durations were $2775 \pm 459 \mathrm{~ms}$ and $3579 \pm 334 \mathrm{~ms}$, respectively.

\section{Mitral cell slow oscillations depend on glomerular glutamatergic synaptic transmission}

We next aimed to determine the source of these MC spontaneous slow oscillations, in particular whether they are generated by intrinsic membrane properties or rely on synaptic activity. We did not observe any significant correlation between MC membrane potential and UP state frequency or UP state amplitude $(r=$ $0.054, p=0.76$ and $r=-0.045, p=0.79$; Fig. $2 A, B$, respectively). This observation suggests that UP state generation does not depend on intrinsic voltage-gated cellular mechanisms, such as the persistent sodium channel activation involved in tufted cells spontaneous depolarizations/bursting (Hayar et al., 2004b). To confirm this hypothesis, we analyzed recordings performed in MCs with a sectioned apical dendrite tuft (as a result of the slicing procedure; Fig. $1 B$ ). In 16 of 17 cases, truncated MCs showed a unimodal distribution of their membrane potential (Fig. $1 B_{3}$ ) associated with a silent state or a tonic firing rate $\left(\right.$ Fig. $\left.1 B_{2}\right)$. This result was unlikely due to the deterioration of $\mathrm{MC}$ viability since they did not display any somatic morphological abnormalities, and their electrophysiological profile was stable across the whole recording duration $(>10 \mathrm{~min})$, with a resting membrane potential $(-53.3 \pm 0.8 \mathrm{mV}, n=17)$ not significantly different from that of MCs with an intact apical dendrite $(-52.9 \pm 0.8 \mathrm{mV}, n=$ 

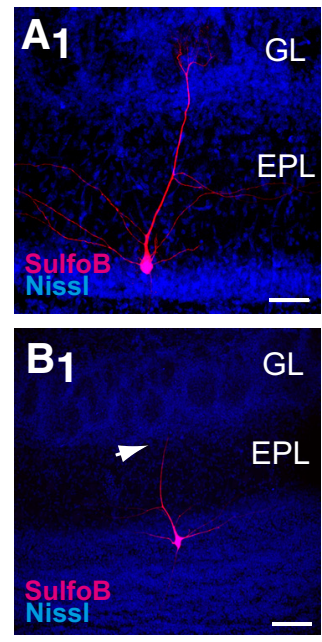

$\mathrm{A}_{2}$ $-55 \mathrm{mV}$

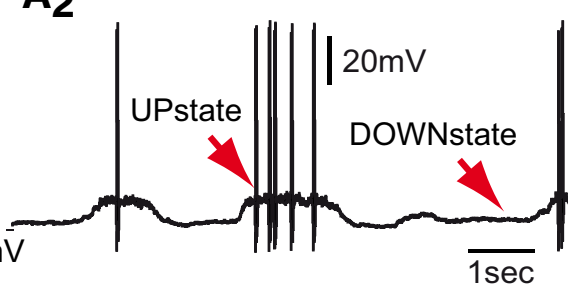

$\mathbf{B}_{2}$

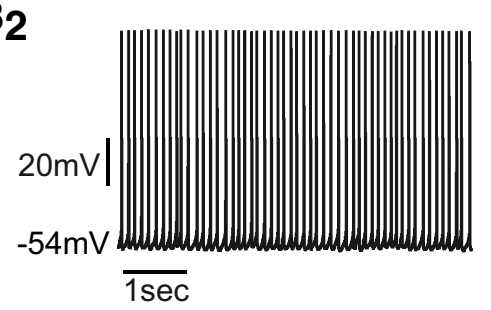

A3

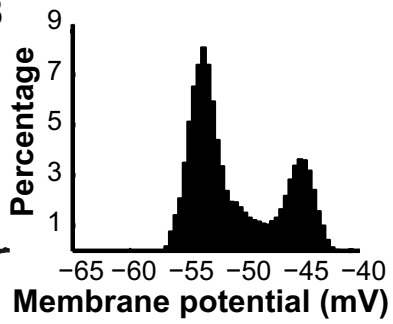

B3

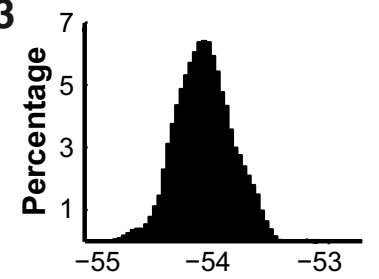

Membrane potential (mV)

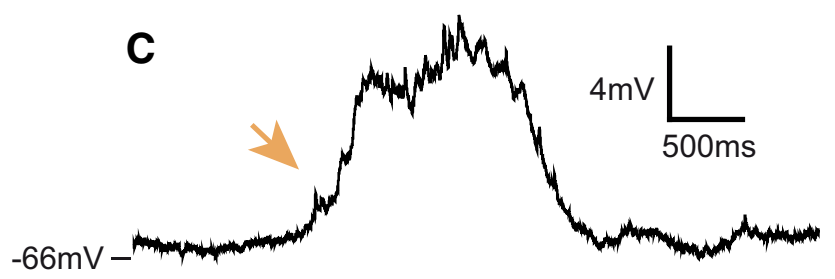

Figure 1. UP and DOWN states in mitral cells are generated in the glomerular layer. $A_{1}$, Mitral cell loaded with SrB (red) during whole-cell recording in olfactory bulb acute slices, with Nissl stain (blue) as a counterstaining. $A_{2}$, Whole cell patch-clamp recording of an MC in the current-clamp configuration. The membrane potential shows spontaneous alternations between depolarized states associated with spikes (UP states) and hyperpolarized silent periods (DOWN states). $\boldsymbol{A}_{3}$, Such activity results in a bimodal distribution. $\boldsymbol{B}_{1}$, Mitral cell with a truncated dendritic apical tuft (arrow). $\boldsymbol{B}_{2}$, $\boldsymbol{B}_{3}$, Patch-clamp recording shows an unimodal distribution of the membrane potential, and $95 \%$ of these truncated MCs display a tonic firing pattern such as the example illustrated in $\boldsymbol{B}_{\mathbf{2}}(n=17)$. Note that none of the MCs with an intact apical dendrite exhibited such a tonic spiking $(n=61)$. C, Example UP state recorded with hyperpolarizing current injection. The membrane potential shows a short buildup of EPSPs before transitioning to the UP state (orange arrow). Scale bars: $50 \mu \mathrm{m}$.
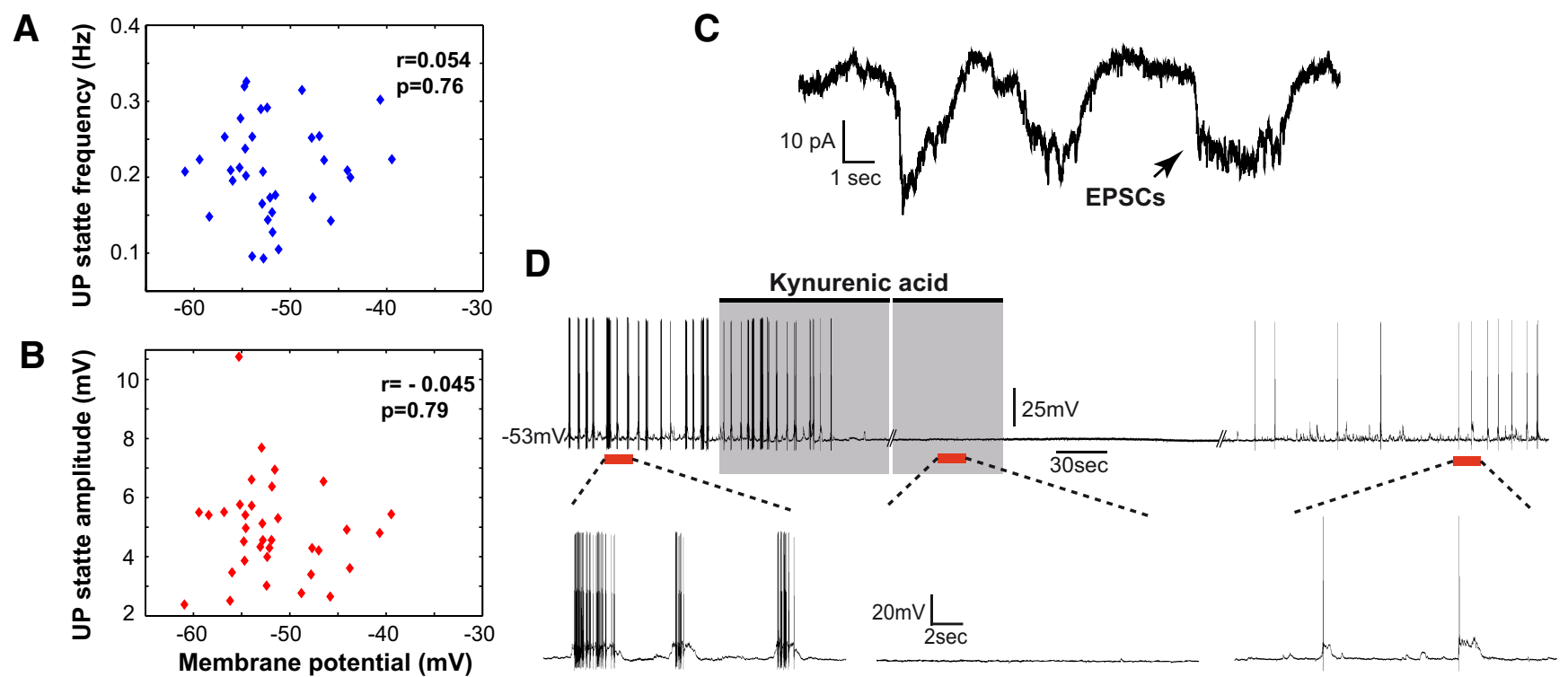

Figure 2. UP and DOWN states in mitral cells require glutamatergic transmission. $A, B$, Absence of correlation between the mean membrane potential of individual MCs and UP state features (frequency and amplitude). Measurements were performed in MC recordings without current injection. $C$, Example of an MC recording in the voltage-clamp configuration at the reversal potential for chloride. Note the slow (inward) excitatory currents, likely corresponding to barrages of EPSCs, the frequency of which is similar to that of UP states $(0.15 \pm 0.06 \mathrm{~Hz}, n=5)$. D, Treatment with kynurenic acid $(2 \mathrm{mM})$, a blocker of ionotropic glutamate receptors, reversibly abolishes UP states generation. Periods indicated by red bars in the top trace are enlarged below. Note that action potentials have been truncated for clarity.

$45, p=0.84$, Mann and Whitney $U$ test). Therefore, apical dendrite tuft integrity at the glomerulus level is required for UP and DOWN states generation in MCs. This result further supports the hypothesis that MC slow oscillations are not generated by intrin- sic membrane properties (at least at the somatic and proximal dendritic levels) and suggests that cell interactions occurring at the level of the glomerular layer are likely responsible for the generation of UP and DOWN states. Although some excitatory 
interactions have been reported to occur between MC lateral dendrites (Aroniadou-Anderjaska et al., 1999b; Didier et al., 2001; Salin et al., 2001), most of the glutamatergic transmission in the OB occurs in the glomerular layer (Isaacson, 1999; Schoppa and Westbrook, 2001, 2002; Urban and Sakmann, 2002; Christie and Westbrook, 2006; De Saint Jan and Westbrook, 2007; Pimentel and Margrie, 2008; De Saint Jan et al., 2009). When MCs were maintained at the reversal potential for chloride in the voltageclamp configuration, large and slow excitatory currents could be observed $(32.8 \pm 8.1$ and $22.8 \pm 5.4 \mathrm{pA}, n=5)$. These events were likely associated with UP states because they occurred at a similar frequency $(0.15 \pm 0.06 \mathrm{~Hz}$; Fig. $2 C)$. To further confirm that excitatory inputs are involved in UP state generation, we directly tested whether ionotropic glutamate receptor activation is necessary for UP/DOWN state alternations. Extracellular application of kynurenic acid (2 $\mathrm{mm}$ ), a nonspecific ionotropic glutamatergic receptor antagonist, completely abolished the occurrence of UP states in a reversible manner $(n=4$; Fig. $2 D)$. Altogether, these results indicate that MC slow oscillations are not mediated by cell intrinsic dynamics, but are dependent on circuit interactions and rely on glutamatergic transmission, most likely in the glomerular layer.

\section{Mitral cell slow oscillations are correlated with glomerular network activity}

Bistability of membrane potential associated with UP and DOWN states, first described in the neocortex during slow wave sleep or under anesthesia (Steriade et al., 1993), has been shown to involve coordinated activity of multiple cortical cells in recurrently connected networks (Timofeev et al., 2000; Sirota and Buzsáki, 2005; Chauvette et al., 2010; Crunelli and Hughes, 2010). We therefore investigated the possibility that similar network activity could occur in OB slices. We recorded LFP with an extracellular electrode placed within the glomerulus where the apical dendrite of a simultaneously recorded MC was located. This was achieved by the inclusion of $\mathrm{SrB}$ in the internal solution of the patch-clamp pipette used for MC recording, which allowed visualizing the MC dendritic projections (Fig. $3 A, D_{1}$, left). Like MC recordings, LFP signals exhibited fluctuations (Fig. $3 D$, middle) in the $0.05-0.5 \mathrm{~Hz}$ frequency range (Fig. $3 B$ ). These fluctuations were strongly correlated with the slow oscillations of the MC membrane potential but in antiphase $(r=-0.69 \pm 0.09, n=4$; Fig. $3 C$ ) and with a short delay ( $\sim 80 \mathrm{~ms}$, Fig. $3 C$, inset). Although the current sources generating the LFP signal in the olfactory glomeruli are still unclear (Aroniadou-Anderjaska et al., 1999a; Karnup et al., 2006), these observed LFP variations suggest that synchronous network activity occurs spontaneously in this ex vivo $\mathrm{OB}$ preparation.

Interestingly, the correlation between LFP and $\mathrm{MC}$ membrane potential fluctuations decreased when the LFP was recorded in a glomerulus adjacent to the glomerulus where the recorded MC projected its apical dendrite, and this correlation was completely abolished for LFP recorded in more distant glomeruli (Fig. $3 D_{2}$ ). Along these lines, when two extracellular electrodes were placed in the same glomerulus (Fig. $3 E_{1}$ ), the correlation between the two signals was strong and progressively decreased with distance (and the number of glomeruli) between the two electrodes (Fig. $3 E_{2}, F$ ). These results suggest that in $\mathrm{OB}$ slices, the spontaneous slow oscillations monitored in a given $\mathrm{MC}$ reflect the activity of a local neuronal circuit in the close proximity of the associated glomerulus, which could act as an independent functional unit.

\section{Neuronal activity promotes connexin-formed hemichannel function in astrocytes}

Altogether, the aforementioned observations show that the spontaneous membrane potential alternations of the MCs in acute $O B$ slice preparations result from glomerular network interactions, where the role of astrocytes could be investigated. Glomerular astrocytes have their soma at the border of the glomerulus and send processes toward the glomerulus center (Bailey and Shipley, 1993; Chiu and Greer, 1996; Roux et al., 2011). Their morphology is thus ideally suited to detect neuronal activity within individual glomeruli, as shown previously (De Saint Jan and Westbrook, 2005; Roux et al., 2011). Indeed, we reported that the membrane potential of glomerular astrocytes oscillates in a correlated manner with the LFP recorded in the same glomerulus (Roux et al., 2011). We also showed that astroglial Cxs are enriched within glomeruli compared to the extraglomerular region (Roux et al., 2011). Aside from their implication in gap junctional communication, these membrane proteins constitute possible candidates for $\mathrm{HC}$ function, allowing exchanges between the intracellular and extracellular media (Bennett et al., 2003; Giaume et al., 2013; Chever et al., 2014; Abudara et al., 2015). To test this possibility, $\mathrm{HC}$ activity was assessed in the $\mathrm{OB}$ by using EtBr uptake assays (Giaume et al., 2012). Ethidium bromide fluorescence was measured in GFAP-immunoreactive cells of the glomerular layer, after postfixation and processing of the slices (see Materials and Methods). We first observed that a large part of the EtBr uptake relied on Cx-formed HCs in astrocytes, as established previously in other preparations (Retamal et al., 2007; Orellana et al., 2009). Indeed, in a double knock-out mouse for the two main astroglial Cxs (Cx30 and Cx43), EtBr fluorescence was divided by two (49.6\% of control) compared to the control condition (Fig. $4 A_{1}, A_{2}, B_{1}, B_{2}, D$ ). Another membrane protein family called pannexins (Panxs) has also been shown to form HCs in astrocyte plasma membranes, at least in cultured astrocytes (Iglesias et al., 2009; Giaume et al., 2013), and accordingly, part of the EtBr uptake could be attributed to Panx channel activity. However, treatment of the slices with carbenoxolone, a blocker of both Cx-formed and Panxformed channels (Giaume et al., 2013), reduced EtBr fluorescence to a level similar to the dKO slices (Fig. 4D). This observation suggests that, unlike Cxs, Panxs make little contribution to EtBr uptake in $\mathrm{OB}$ astrocytes.

Because glomerular astrocytes are able to detect spontaneous neuronal activity (Roux et al., 2011), the possible impact of this activity on astroglial $\mathrm{HC}$ function was next investigated. Interestingly, we found that EtBr uptake was strongly reduced (to $57 \%$ of control) when spontaneous neuronal activity was inhibited by TTX treatment (Fig. $4 C_{1}, C_{2}, E$ ). Importantly, this inhibition was not observed in slices from dKO mice (Fig. $4 E$ ), indicating that $\mathrm{Cx}$ HCs are the main targets of this activitydependent EtBr uptake. Altogether, these results show that spontaneous neuronal activity promotes the activation of $\mathrm{Cx}$ formed HCs in astrocytes.

\section{Astroglial connexins impact mitral cell slow oscillations}

Since astroglial Cx HCs are open in an activity-dependent manner in OB slices, we then asked whether they have, in turn, an impact on neuronal activity. Because the pharmacology of $\mathrm{Cx}$ channels is largely unspecific (Giaume and Theis, 2010), we first addressed this question using $\mathrm{Cx} \mathrm{dKO}$ mice in which astrocytes lack Cx43 and Cx30 expression (Wallraff et al., 2006). 
A
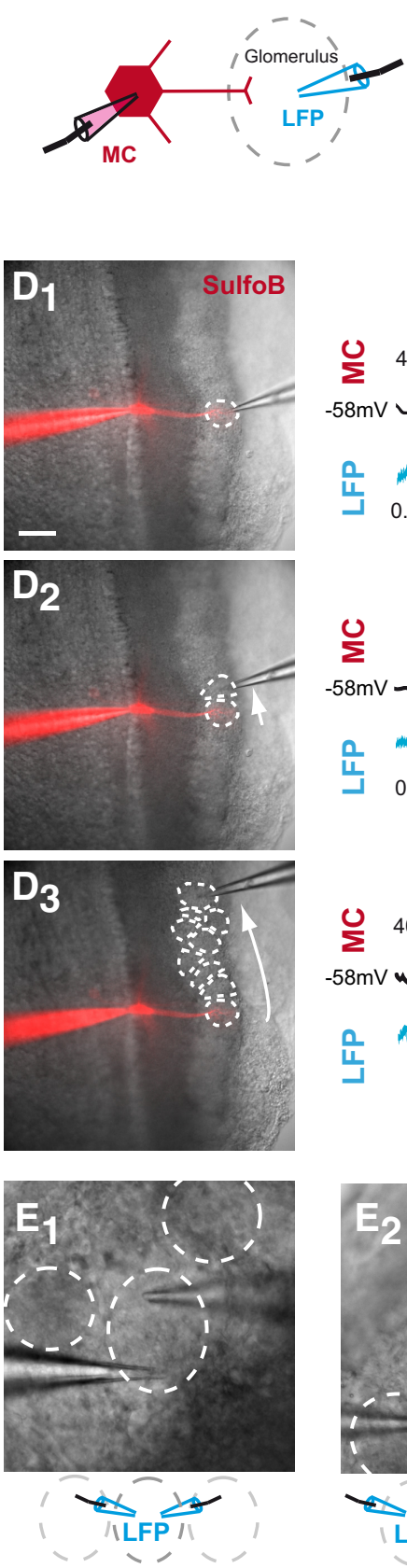

B

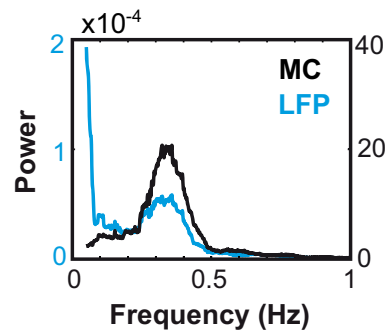

C
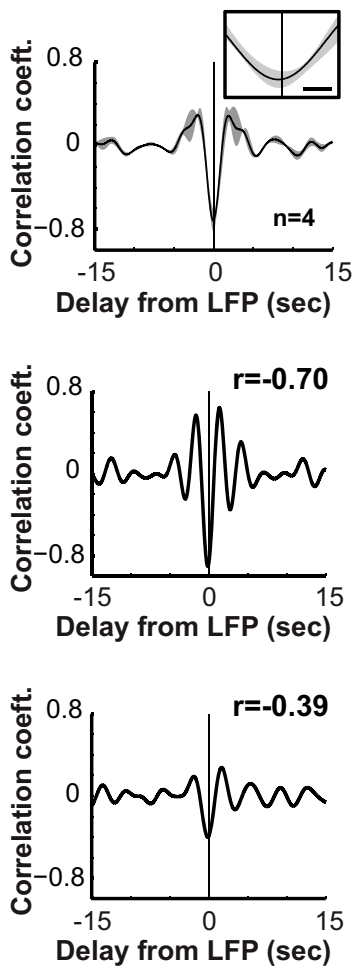
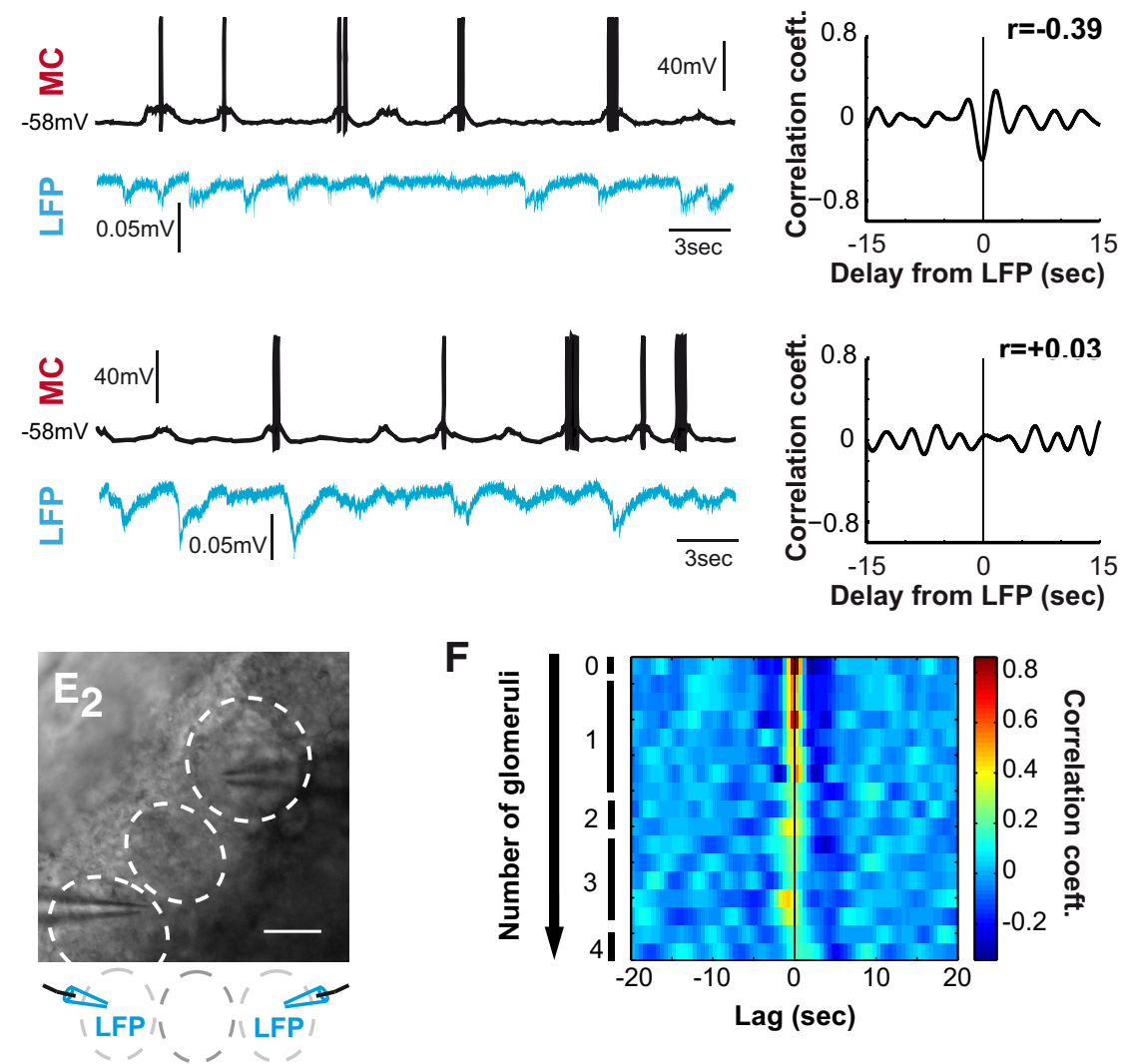

$\mathbf{F}$

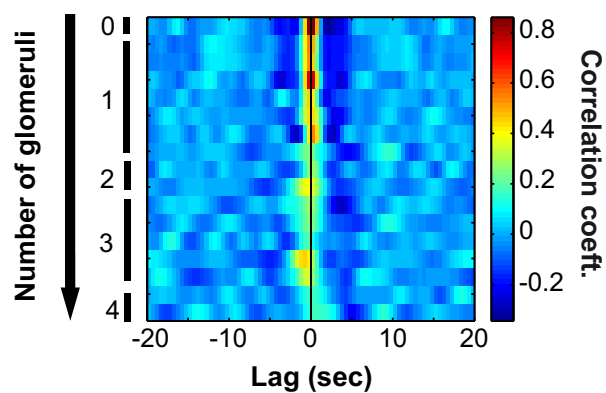

Figure 3. Mitral cell slow oscillations are correlated with glomerular network activity in olfactory bulb acute slices. $A$, Schematic drawing of the recording configuration (the whole-cell pipette used to record $M C$ membrane potential contained SrB; red). Diffusion of the dye within the $M C$ allowed localizing the glomerulus where its primary dendrite projected. The glomerular LFP was recorded with an extracellular pipette (blue) located in this glomerulus. $\boldsymbol{B}$, Power spectrum of two typical signals illustrated in $\boldsymbol{D}_{1}$ : both $M C$ membrane potential (black) and LFP signals (blue) present a prominent component in the slow $(0.05-0.5 \mathrm{~Hz})$ frequency range. C, Averaged cross-correlogram between MC and LFP signals (LFP being the reference) shows a strong correlation between these two signals $(r=-0.69 \pm 0.09, n=4)$. Note that the MC precedes the LFP with a delay of $\sim 80 \mathrm{~ms}$. The gray area indicates the SEM, and the inset highlights the $2 \mathrm{~s}$ surrounding the zero lag value (scale bar: $500 \mathrm{~ms}$ ). $\boldsymbol{D}_{\mathbf{1}}-\boldsymbol{D}_{\mathbf{3}}$, Left, DIC images corresponding to the recordings shown in the center. Glomeruli are delimited by dotted lines, and the MC is loaded with SrB (red). Scale bar, $100 \mu \mathrm{m}$. Center, mitral cell membrane potential and LFP in the glomerular layer recorded simultaneously. Deflections visible in the glomerular LFP indicate coherent network activity. Right, Cross-correlograms corresponding to the signals depicted in the central panels. $\boldsymbol{D}_{1}$, Typical recordings of an MC and the LFP (blue) monitored in the glomerulus where the MC sends its primary dendrite (see diagram in $\boldsymbol{A}$ ). $\boldsymbol{D}_{2}$, Recording of the same MC as in $\boldsymbol{D}_{\mathbf{1}}$ with the LFP monitored in the adjacent glomerulus. $\boldsymbol{D}_{3}$, Recording of the same MC as in $\boldsymbol{D}_{1}$ and $\boldsymbol{D}_{2}$ with the LFP monitored in a distant glomerulus. The absolute value of the correlation between the two signals is higher $(r=-0.70)$ for the LFP monitored in the glomerulus where the MC projects its principal dendrite (D1) than for the LFP recorded in adjacent $\left(r=-0.39 ; \mathbf{D}_{2}\right)$ or distant $(r=0.03$; $\boldsymbol{D}_{3}$ ) glomeruli. $\boldsymbol{E}_{1}, \boldsymbol{E}_{2}$, LFPs in the glomerular layer were recorded simultaneously within the same glomerulus $\left(\boldsymbol{E}_{1}\right)$ and or two different glomeruli $\left(\boldsymbol{E}_{2}\right) . \boldsymbol{F}_{1}$ (ross-correlations between pairs of LFP signals recorded in the glomerular layer. Each row corresponds to the recording of one pair of glomeruli. The number of glomeruli between recording sites is indicated on the left, with 0 corresponding to recordings in the same glomerulus (like in $\boldsymbol{E}_{1}$ ). Values computed for cross-correlation (calculated for $\sim 500 \mathrm{~s}$ of the filtered signals) are color coded. Note that cross-correlation is higher for LFPs monitored in the same glomerulus than for LFP recorded in different glomeruli. 

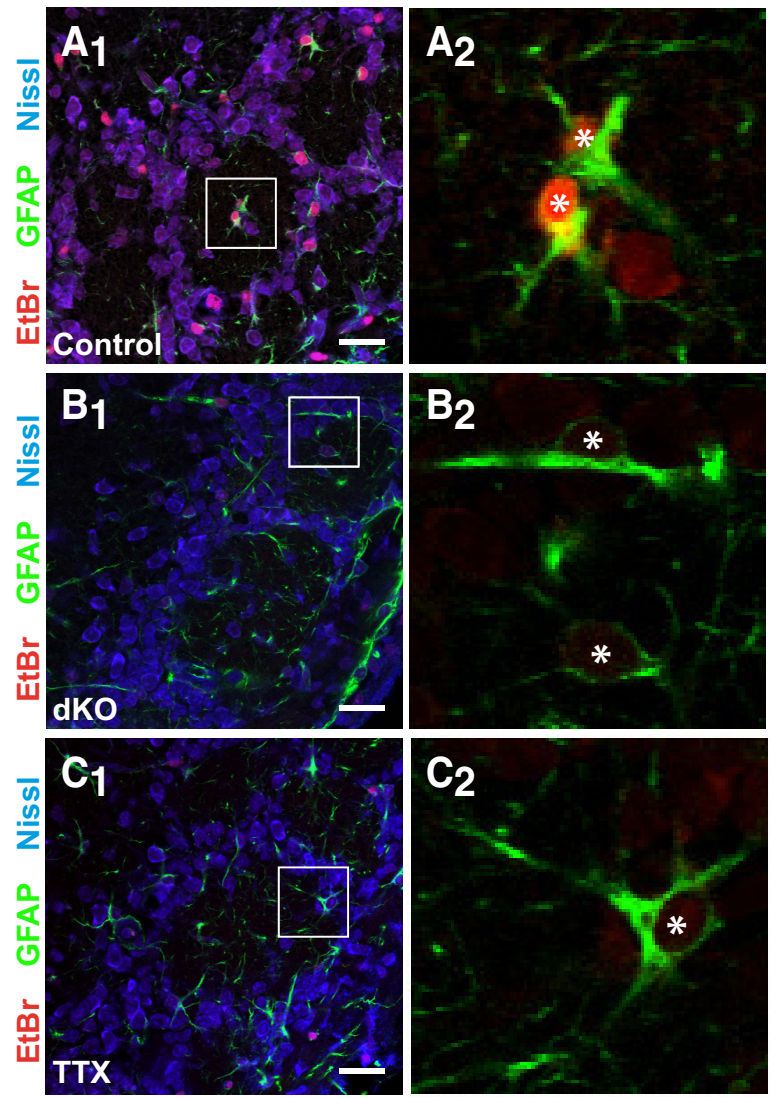

Figure 4. Spontaneous neuronal activity promotes astroglial connexin-formed hemichannels opening in the olfactory bulb glomerular layer. Hemichannel activity was assessed by ethidium bromide (red) uptake assays. $\boldsymbol{A}_{1}-\boldsymbol{C}_{2}$, Astrocytes (asterisks) are identified by GFAP immunoreactivity (green), and Nissl (blue) is used as a counterstaining. Higher magnifications are shown in the right panels corresponding to the areas delimited by white squares in the left panels. EtBr fluorescence in astrocytes is reduced by deletion of $\mathrm{C} \times 30$ and $\mathrm{Cx} 43\left(\mathrm{dKO} ; \boldsymbol{B}_{1}, \boldsymbol{B}_{2}\right)$ and by TTX application $\left(\boldsymbol{C}_{1}, \boldsymbol{C}_{2}\right)$. Scale bars, $25 \mu \mathrm{m}$. $\boldsymbol{D}$, EtBr uptake is reduced by $\mathrm{C}$ deletion (50.4\% inhibition) and application of CBX (40.8\%; $100 \mu \mathrm{m} ; n=682,356$, and 201 cells in control, dKO, and CBX conditions, respectively; one way ANOVA, $p<0.001$; post hoc Tukey's multiple comparison test, ${ }^{* * *} p<0.001$ ). Note that EtBr uptakes in dKO and $C B X$ conditions are not significantly different. For each condition, fluorescence values are expressed as a function of the mean fluorescence value obtained in the WT control condition of each assay (see Materials and Methods). $\boldsymbol{E}$, EtBr uptake is reduced by $43.1 \%$ when spontaneous neuronal activity is inhibited by TTX in the WT (one way ANOVA, $p<0.001$; post hoc Tukey's multiple comparison test, ${ }^{* * *} p<0.001$ ), but not in absence of astroglial Cxs (dKO). The effect of TTX treatment in the dKO is significantly reduced compared to WT (two-way ANOVA, ${ }^{\# \# \#} p<0.001$ for the interaction). Note that EtBr uptake values in WT + TTX and dKO conditions are not significantly different.

Patch-clamp recordings showed that MCs in dKO mice also undergo spontaneous UP and DOWN states (Fig. 5B). Only MCs with clear UP and DOWN states and allowing long stable recordings ( $>10 \mathrm{~min}$ ) were included in the analysis ( 39 of 74 for WT, 38 of 79 for $\mathrm{dKO} ; p=0.75$, Fisher's exact test). We observed that the frequency of UP states was similar in both mouse lines (WT, $0.20 \pm 0.01 \mathrm{~Hz}, n=39 ; \mathrm{dKO}, 0.22 \pm 0.01 \mathrm{~Hz}, n=38 ; p=0.43$; Fig. $5 C$ ), indicating that the frequency of the OB slow oscillations does not depend on Cx expression in astrocytes. Similarly, no difference was detected between WT and dKO MCs for UP and DOWN state durations (Fig. 5D,E): UP states lasted $1662 \pm 82$ $\mathrm{ms}$ and $1648 \pm 133 \mathrm{~ms}$ in WT and $\mathrm{dKO} \mathrm{MCs}$, respectively; DOWN state duration was $3694 \pm 272 \mathrm{~ms}$ and $3685 \pm 279 \mathrm{~ms}$ in WT and $\mathrm{dKO}$ MCs, respectively. However, UP state amplitude was significantly reduced in $\mathrm{dKO}$ mice $(4.5 \pm 0.2 \mathrm{mV})$ compared to WT mice $(6.0 \pm 0.3 \mathrm{mV}$; Fig. $5 F)$. Noteworthy, the difference in UP state amplitude reported here for cells maintained at -60 $\mathrm{mV}$ was also observed for cells monitored at their spontaneous membrane potential, without current injection. Indeed, whereas membrane potential was not significantly different in WT and
dKO MCs (WT, $-52.9 \pm 0.8 \mathrm{mV}, n=45$; $\mathrm{dKO},-52.1 \pm 0.6 \mathrm{mV}, n=32 ; p=0.26$, Mann and Whitney $U$ test), the UP state amplitude was smaller in $\mathrm{dKO}$ MCs (WT, $4.43 \pm 0.26 \mathrm{mV} ; \mathrm{dKO}, 3.53 \pm 0.20 \mathrm{mV}$; $p=0.01)$. Interestingly, this reduction in UP state amplitude in dKO MCs was associated with a significant reduction ( $\sim 36 \%$ ) of the firing rate during UP states compared to WT MCs (Fig. 5G). Based on these observations, we concluded that $\mathrm{Cx}$ expression in astrocytes has an impact on MC slow oscillations and their spontaneous firing rate.

Astroglial hemichannels modulate MC slow oscillations

Because the use of Cx knock-out animals does not allow discriminating between $\mathrm{Cx}$-mediated gap junction channel and HC functions, we used Gap26, a mimetic peptide, to specifically target $\mathrm{Cx} 43 \mathrm{HC}$ function (Chaytor et al., 1997) in OB slices. This peptide, which presents a sequence of amino acids similar to a portion of the first extracellular loop of $\mathrm{Cx} 43$, has been shown to prevent $\mathrm{Cx} 43 \mathrm{HC}$ opening in astrocytes (Retamal et al., 2007; Chever et al., 2014; Abudara et al., 2015) and Cx43-transfected cells (Desplantez et al., 2012; Wang et al., 2012). Notably, we conducted short applications of Gap26 $(<15$ min) to prevent the potential effects on gap junctional communication that have been described for longer treatments (>30 min) (Desplantez et al., 2012). To mimic the $\mathrm{dKO}$ condition regarding $\mathrm{HC}$ function, we intended to block all potential Cx-formed HCs in astrocytes. Since there is currently no tool to specifically block Cx30 HCs, we performed Cx43 HCs inhibition with Gap26 in OB slices from Cx30 KO mice (Teubner et al., 2003). In these conditions, we confirmed by EtBr uptake assays that Gap26 inhibits $\mathrm{HC}$ activity in astrocytes, as indicated by a $37 \%$ decrease in EtBr fluorescence in GFAP positive cells (Cx30 KO, 88.1 \pm $1.9 \%$ of control; $\mathrm{Cx} 30 \mathrm{KO}+\mathrm{Gap} 26,64.5 \pm 2.3 \%$ of control; $p<$ $0.001 ; n=687$ and 308 for control and Gap26 conditions, respectively; two-tailed $t$ test; Fig. $6 A_{1}, A_{2}$ )

We then aimed to determine the effect of Gap26 treatment on MC slow oscillations. Patch-clamp recordings allowed determining UP and DOWN state characteristics prior to and after Cx43 HCs blockage in individual $\mathrm{Cx} 30 \mathrm{KO}$ MCs maintained at -60 $\mathrm{mV}$. We observed that $\mathrm{Cx} 43 \mathrm{HC}$ inhibition by Gap26 significantly reduces the amplitude of the UP state (Fig. $6 B_{1}$ ). Importantly, the amplitude observed after Gap26 treatment was similar to the amplitude reported in the $\mathrm{dKO}$ (Fig. 6C). In parallel, we performed the same experiment with $\mathrm{dKO} M C$ s to test for potential unspecific effects of Gap26. In this case, Gap26 treatment had no detectable effect on $\mathrm{dKO} \mathrm{MC}$ slow oscillation amplitude (Fig. $\left.6 B_{2}, C\right)$, demonstrating that the impact of Gap 26 on MCs UP state amplitude requires astroglial Cx expression. The reduction in UP state amplitude in the $\mathrm{Cx} 30 \mathrm{KO}$ cannot be explained by an in- 
crease in $R_{\mathrm{a}}$ over the course of the recording, because we did not observe any significant correlation between these two measures $(p=0.46)$. Moreover, when comparing the beginning and the end of the recordings, changes in $R_{\mathrm{a}}$ were not different between $\mathrm{Cx} 30 \mathrm{KO}$ and $\mathrm{dKO} \mathrm{MCs}$ ( $p=0.64$, two-tailed Mann and Whitney $U$ test), although the reduction in UP state amplitude was observed only in the $\mathrm{Cx} 30$ KO MCs (Fig. 6C). To rule out a potential effect of the development stage, we divided our $\mathrm{Cx} 30 \mathrm{KO}$ recordings into two groups depending on the mouse postnatal age (P14-P18 and P19-P25). Since Gap26 reduced UP state amplitude to a similar extent in both groups (interaction, $p=0.99$; treatment effect, $p=0.01$; age effect, $p=0.11$; repeated-measures twoway ANOVA), we concluded that within the $\mathrm{P} 14-\mathrm{P} 25$ range, the developmental stage cannot account for differences in the Gap26 effect. An additional control was performed using a scrambled peptide: although it was composed of the same amino acids as Gap26, it did not impact MC UP state amplitude $(5.26 \pm 0.31 \mathrm{mV}$ vs $5.13 \pm 0.14 \mathrm{mV}$ for control and scramble conditions, respectively; two-tailed Wilcoxon matched-pairs signed rank test, $p=$ $0.88 ; n=4)$. Altogether, these observations indicate that $\mathrm{Cx} 43 \mathrm{HC}$ activity increases the amplitude of MC UP states.

Connexin 43 , but not connexin 30 , is involved in the modulation of MC slow oscillations

Because the above experiments were performed in $\mathrm{Cx} 30 \mathrm{KO}$ slices, we could not exclude that Cx30 HCs and/or Cx30mediated gap junction channels are also involved in the modulation of MC slow oscillations. To evaluate the respective contribution of $\mathrm{Cx} 30$ and $\mathrm{Cx} 43$, we used knock-out mice in which these Cxs were singly deleted in astrocytes (Teubner et al., 2003; Theis et al., 2003). We found that the frequency of the UP states in these mice was similar to that in WT and $\mathrm{dKO}$ MCs $(\mathrm{Cx} 43 \mathrm{KO}$ mice, $0.22 \pm 0.03 \mathrm{~Hz}, n=10$; $\mathrm{Cx} 30 \mathrm{KO}$ mice, $0.21 \pm$ $0.01 \mathrm{~Hz}, n=22)$. Again, no difference was detected for UP and DOWN state durations among the tested mouse lines: UP states lasted $1276 \pm 169 \mathrm{~ms}$ and $1756 \pm 145 \mathrm{~ms}$ in $\mathrm{Cx} 43 \mathrm{KO}$ and $\mathrm{Cx} 30$ KO MCs, respectively, whereas DOWN state durations reached $4085 \pm 885 \mathrm{~ms}$ and $3440 \pm 264 \mathrm{~ms}$ in $\mathrm{Cx} 43 \mathrm{KO}$ and $\mathrm{Cx} 30 \mathrm{KO}$ MCs, respectively. However, whereas UP state amplitude was not affected by $\mathrm{Cx} 30$ deletion $(5.8 \pm 0.3 \mathrm{mV})$, it was significantly reduced in the $\mathrm{Cx} 43 \mathrm{KO}$, to a similar extent as in the $\mathrm{dKO}(\mathrm{Cx} 43 \mathrm{KO}, 4.3 \pm 0.5 \mathrm{mV}$; dKO, $4.5 \pm 0.2 \mathrm{mV}$; Fig. $6 D)$. Importantly, we did not observe any difference in $R_{\mathrm{a}}$ for the MCs recorded in the four different genotypes (one-way ANOVA, $p=0.47$ ), indicating that disparities in $R_{\mathrm{a}}$ cannot be accounted for the reported differences in UP state amplitudes. Based on these observations, we concluded that Cx30 expres-
A Wild type

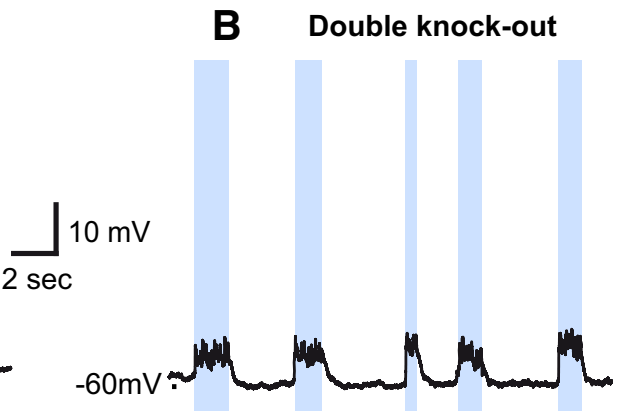

\section{B Double knock-out}

E DOWN state duration

U UP state duration
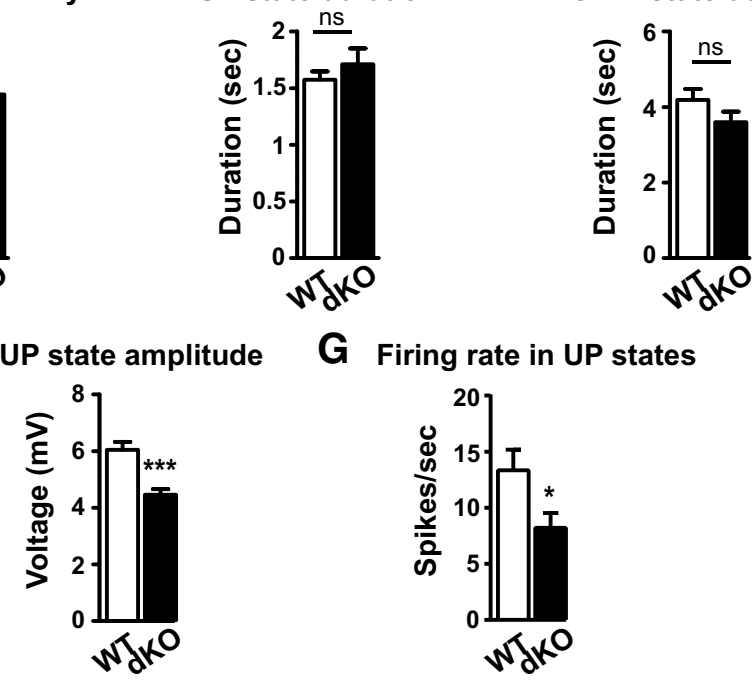

Firing rate in UP states

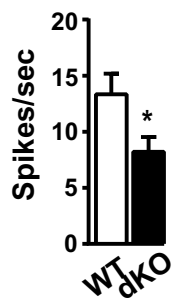

Figure 5. The lack of connexin expression in astrocytes impacts slow oscillations in olfactory bulb slices. $\boldsymbol{A}, \boldsymbol{B}$, Typical mitral cell ectangles. Note that action potentials have been truncated for clarity. To allow comparison, cells were maintained at $-60 \mathrm{mV}$ by (injection. $C-F$, Mitral cell oscillatory properties were examined in WT and dKO mice. $C$, The frequency of the UP states is not differences are detected for UP and DOWN state durations between WT and dKO MCs (two-tailed Mann and Whitney $U$ test, $p=$ 0.46 and 0.94 , respectively). $\boldsymbol{F}$, However, a significant reduction in the amplitude separating the DOWN from the UP state membrane potentials (defined as UP state amplitude) is observed in dKO MCs compared to WT MCs. ${ }^{* * *} p<0.0001$ (two-tailed Mann and Whitney $U$ test). Similar results were obtained for recordings performed without current injection. $\mathbf{G}$, The firing rate during UP states is reduced in $\mathrm{dKO}$ compared to WT MCs when cells are monitored at spontaneous membrane potential (WT, $n=45$; dKO, $n=32$ ). ${ }^{*} p=0.04$ (one-tailed Mann and Whitney $U$ test).

sion in astrocytes has no impact on the amplitude of MC slow oscillations. Instead, $\mathrm{Cx} 43$, and in particular $\mathrm{Cx} 43 \mathrm{HC}$ function, plays a crucial role in this phenomenon.

\section{Connexin 43 hemichannel contribution to MC slow} oscillation requires adenosine A1 receptor function

Connexin 43 HCs have been shown to be permeable to several compounds that have an impact on neuronal activity (Bennett et al., 2003; Giaume et al., 2013), a major one being ATP (Kang et al., 2008; Torres et al., 2012; Chever et al., 2014). Based on these observations, we first tested whether ATP is released through $\mathrm{Cx} 43 \mathrm{HCs}$ in our conditions. We performed extracellular ATP dosage with bioluminescence assays on $\mathrm{OB}$ slices from $\mathrm{Cx} 30 \mathrm{KO}$ and $\mathrm{dKO}$ mice, with and without Gap26 treatment. Connexin43 HC blockade by Gap26 reduced extracellular ATP levels by $\sim 50 \%$ in control $\mathrm{Cx} 30 \mathrm{KO}$ slices, but not in $\mathrm{dKO}$ slices, where both Cxs are lacking (Fig. 7). The reduction of ATP levels induced by Gap26 in control slices was similar to the reduction induced by $\mathrm{Cx}$ gene deletion ( $\mathrm{dKO}$ condition). We then investigated whether Cx43 HC blockade also reduces extracellular ATP levels when 

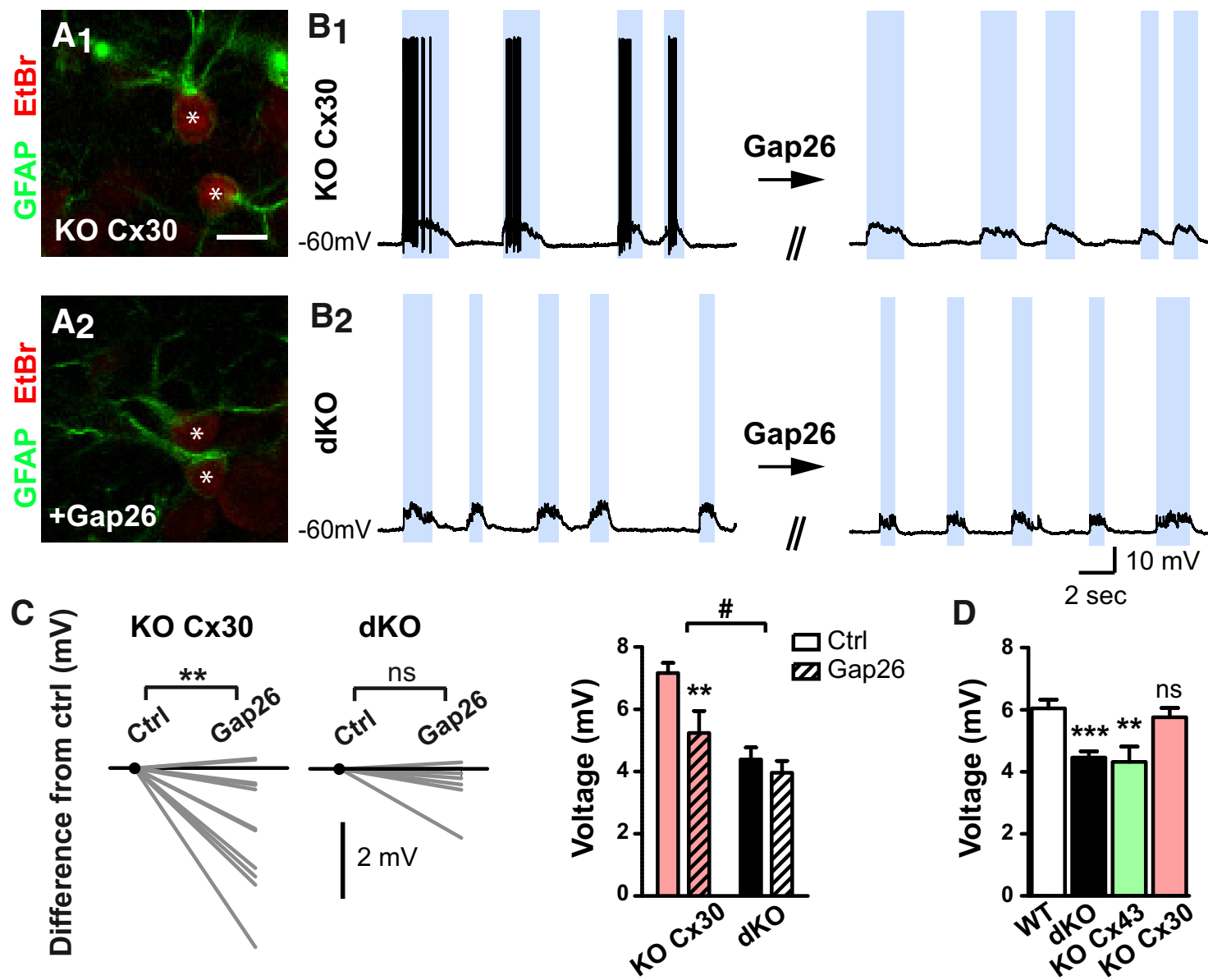

Figure 6. Blockade of $\mathrm{Cx} 43$ hemichannels impacts mitral cells slow oscillations. $A_{1}, A_{2}$, Examples of EtBr (red) fluorescence in the absence (A1) or presence (A2) of Gap26 in the $C \times 30$ K0. GFAP immunostaining (green) was used to identify astrocytes (asterisks). Scale bar, $10 \mu \mathrm{m}$. $\boldsymbol{B}_{1}$, Example of MC recording in (x30 K0 slices, before and after Gap26 application. $\boldsymbol{B}_{2}$, Example of MC recording in dKO slices, before and after Gap26 application. Detected UP states are highlighted by blue rectangles. C, Left, Effect of Gap26 application on UP state amplitude in Cx30 K0 and dK0 MC recordings. Each gray line represents measures obtained for individual MCs before and after Gap26 treatment. C, Right, Blockade of Cx43 HCs in the Cx30 K0 reduced UP state amplitude ${ }^{* *} p=0.002$, two-tailed Wilcoxon matched-pairs signed rank test) to the level of dKO MCs ( $p=0.58$, two-tailed Mann and Whitney $U$ test). This effect was occluded in $\mathrm{dKO} \mathrm{MCS}$, where UP state amplitude is not affected by Gap26 ( $p=0.11$, two-tailed Wilcoxon matched-pairs signed rank test; $\#=0.04$, two-way ANOVA, interaction; $n=$ 12 and 7 for $(x 30 \mathrm{~K} 0$ and dK0, respectively). D, Impact of $(x 30$ and $(x 43$ on MC UP state amplitude. Mitral cell properties were examined in WT, single knock-outs (Cx43 K0 and $\times 30$ K0), and double knock-out (dK0) mice. Like dK0 MCs, Cx43 K0 MCs showed a significant reduction UP state amplitude compared to WT. In contrast, MC behavior was not altered by $\mathrm{x} 30$ deletion in astrocytes $\left(p<0.001\right.$, one-way ANOVA followed by Newman-Keuls post hoc tests; ns, $p>0.05 ;{ }^{* *} p<0.01 ;{ }^{* * *} p<0.001$, compared to WT MCs; WT, $n=39 ;$ dK0, $n=$ 38 ; $(x 43 \mathrm{~K} 0, n=10 ;(\mathrm{x} 30 \mathrm{~K} 0, n=22)$.

A

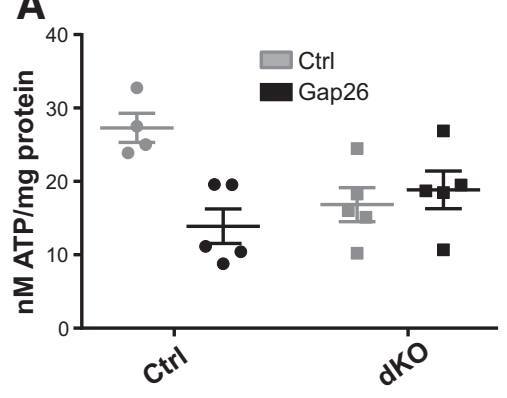

B

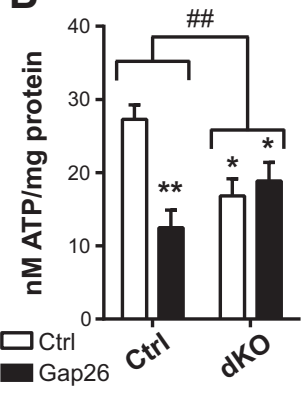

Figure 7. Cx43 hemichannel function increases extracellular ATP levels. $A$, Extracellular ATP levels measured by bioluminescence assays are shown for individual experiments $(n=4,5,5$, and 5 in each condition, respectively). $\boldsymbol{B}$, Group data and statistics. Blockade of $\mathrm{Cx} 43 \mathrm{HCs}$ with Gap26 in CX30 KO (Ctrl) reduces ATP levels to a similar extent as Cx gene removal (dKO condition; $p=0.69$, two-tailed Mann and Whitney $U$ test; $p<0.001$, one-way ANOVA followed by Newman-Keuls post hoc tests; ${ }^{*} p<0.05,{ }^{* *} p<0.01$ compared to control without Gap26) but has no effect in dKO OB slices ( ${ }^{\# \#} p=0.005$, two-way ANOVA, interaction).

neuronal spiking is blocked by TTX. TTX treatment itself decreased ATP levels compared to control, and the resulting ATP levels were not significantly different from ATP levels in the Gap26 condition (control, $39.49 \pm 4.70 \mathrm{nM}$ ATP/mg protein; TTX, $28.42 \pm 5.16 \mathrm{~nm}$ ATP/mg protein; Gap26, $17.97 \pm 4.37 \mathrm{~nm}$ $\mathrm{ATP} / \mathrm{mg}$ protein; $n=8$ independent experiments; repeated measures one-way ANOVA followed by Newman Keuls post hoc tests, $p=0.001)$. This result is consistent with our previous observation that TTX suppresses HC opening as assessed by EtBr uptake assays (Fig. 4E). Importantly, we also observed that TTX treatment occludes the suppressing effect of the Gap26 on ATP levels $(21.98 \pm 5.15 \mathrm{~nm}$ ATP/mg protein for TTX + Gap26 condition; repeated measures two-way ANOVA; interaction, $p=0.04$ ). These results indicate that ATP release is associated with $\mathrm{Cx} 43$ $\mathrm{HC}$ activity in $\mathrm{OB}$ slices, as shown previously in other brain regions (Kang et al., 2008; Torres et al., 2012; Chever et al., 2014), and that at least part of the ATP release that relies on $\mathrm{Cx} 43 \mathrm{HC}$ opening is dependent on neuronal activity.

ATP is rapidly catabolized into adenosine by ectonucleotidases in the extracellular space (within $\sim 200 \mathrm{~ms}$; Dunwiddie et 

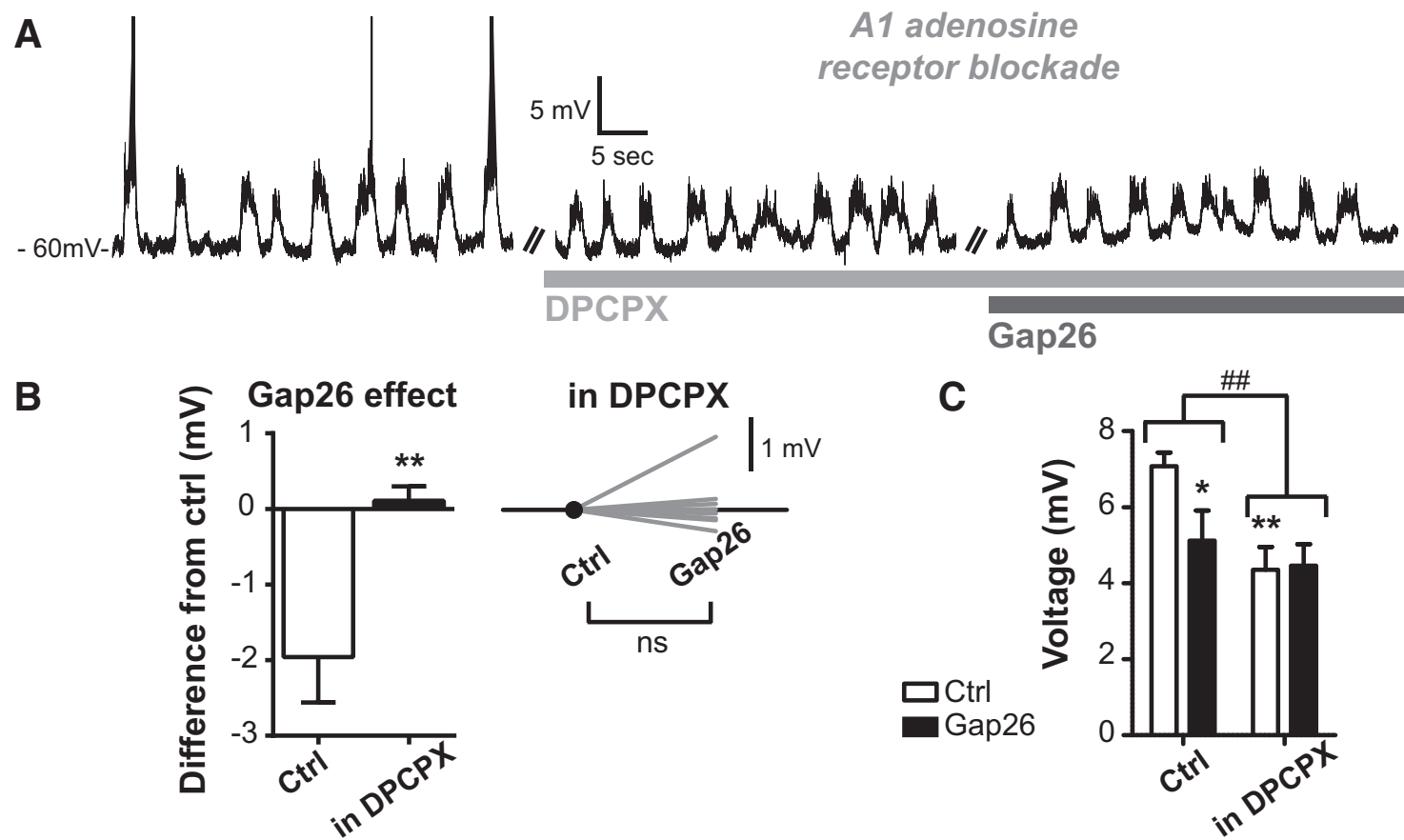

Figure 8. Connexin 43 hemichannels modulation of slow oscillations requires adenosine A1 receptor function. $A$, Example of MC recording with successive application of the adenosine A1 receptor blocker DPCPX, followed by Gap26 (combined to DPCPX). $\boldsymbol{B}$, Left, Mean effect of Gap26 treatment on UP state amplitude, in presence or absence of DPCPX. ** $p=0.005$ (Mann and Whitney $U$ test; $n=8$ for both control and DPCPX conditions). Right, Effect of Gap26 treatment on UP state amplitude for individual cells in the presence of DPCPX ( $p>0.99$, two-tailed Wilcoxon matched-pairs signed rank test). C, Application of the adenosine A1 receptor antagonist DPCPX occluded the reducing effect of Gap26 on UP state amplitude in MCs. ${ }^{*} p=0.01$ (effect of Gap26 compared to control condition, without DPCPX; two-tailed Wilcoxon matched-pairs signed rank test); ${ }^{\# \#} p=0.006$ (two-way ANOVA, interaction).

al., 1997) and purinergic signaling depends on a delicate balance between ATP and adenosine (Poskanzer and Yuste, 2011; Lohr et al., 2014). In the OB, the balance ATP/adenosine is likely in favor of adenosine since the ecto- $5^{\prime}$-nucleotidase, an enzyme responsible for the dephosphorylation of AMP to adenosine (the last step of ATP conversion to adenosine), is highly expressed in this region (Langer et al., 2008). Thus, we questioned whether adenosine originating from astroglial ATP could be involved in the modulation of MC UP state amplitude mediated by Cx43 HCs.

Typically, adenosine can activate two main types of receptors, the $\mathrm{A} 2 \mathrm{~A}$ and $\mathrm{A} 1$ adenosine receptors, which have opposite effects on neuronal function: in most brain areas, A2A receptor activation is facilitating, whereas A1 receptor activation suppresses neuronal activity at the single cell level (Cunha, 2001). Both types of purinergic receptors are expressed in the OB (Dixon et al., 1996; Kaelin-Lang et al., 1999). We first tested the impact of A2 receptor activation on UP state amplitude by recording MCs in the presence of ZM 241385 (10 nM), an antagonist of A2 receptors. This treatment had no effect on MC UP state amplitude $(4.80 \pm 0.88 \mathrm{mV}$ vs $4.78 \pm 0.75 \mathrm{mV}$ in control and ZM 241385 conditions, respectively; two-tailed Wilcoxon matched-pairs signed rank test, $p=0.84 ; n=6$ for both conditions), ruling out the involvement of $\mathrm{A} 2$ receptors in the modulation of UP states by Cx43 HCs. In contrast, we found that a blockade of A1 receptors with DPCPX (200 nM) reduced the amplitude of UP states (7.1 $\pm 0.4 \mathrm{mV}, n=8$ vs $4.4 \pm 0.6 \mathrm{mV}, n=8$ for control and DPCPX conditions, respectively; Fig. $8 A, C$ ). This observation suggests that adenosine, of astroglial and/or neuronal origin, can increase UP state amplitude via $\mathrm{A} 1$ receptor activation.

To test whether adenosine $\mathrm{A} 1$ receptor activation is involved in the modulation of MC UP states via $\mathrm{Cx} 43 \mathrm{HCs}$, we reiterated Gap26 experiments in Cx30 KO slices, but in the presence of DPCPX (Fig. 8A). We found that, in addition to a reducing effect on UP state amplitude (Fig. 8C), DPCPX completely occludes the inhibition of MC UP state amplitude associated with Gap26 treatment (Fig. $8 \mathrm{~A}, \mathrm{C}$ ), suggesting that $\mathrm{A} 1$ receptor activation is downstream to ATP/adenosine release through $\mathrm{Cx} 43 \mathrm{HCs}$. Altogether, these observations indicate that astroglial $\mathrm{Cx} 43 \mathrm{HCs}$ control the level of extracellular ATP and that A1 receptor activation by its metabolite, adenosine, is a critical step in the modulation of MC slow oscillations by $\mathrm{Cx} 43 \mathrm{HC}$ activity.

\section{Discussion}

Spontaneous slow oscillations persist in $\mathrm{OB}$ acute slices, both at the single cell and network levels, as revealed by UP and DOWN states in MCs correlated with slow fluctuations in the glomerular LFPs. We show here that this spontaneous neuronal activity promotes the opening of $\mathrm{Cx} 43 \mathrm{HCs}$ in astrocytes. We further demonstrate that in turn, astroglial $\mathrm{Cx} 43 \mathrm{HC}$ activity controls extracellular ATP levels and impacts the amplitude of MC UP states via $\mathrm{A} 1$ receptor activation. Our results uncover a neuroglial dialog, where $\mathrm{Cx} 43 \mathrm{HC}$ function in astrocytes is both a target and a modulator of neuronal network function in the OB.

\section{Astroglial connexin hemichannels, both targets and actors in neuroglial interactions}

Hemichannel activity in astroglia has been described previously in pathological (Contreras et al., 2003; Retamal et al., 2007; Orellana et al., 2009; Abudara et al., 2015) and, more recently, in physiological conditions (Stehberg et al., 2012; Torres et al., 2012; Chever et al., 2014). Our results extend this knowledge by showing that $\mathrm{HC}$ opening in astrocytes, as well as their impact on extracellular ATP levels, depends on neuronal activity (Fig. 4E). The mechanism by which spontaneous neuronal activity promotes astroglial HC function may rely on the local decrease in 
extracellular calcium induced by glutamatergic neuronal function, as shown in hippocampal slices (Torres et al., 2012).

Our observations indicate that, as opposed to $\mathrm{HC}$ function, gap junction-mediated communication plays a minor role with respect to the modulation of spontaneous $\mathrm{OB}$ slow oscillations. Indeed, the blockade of $\mathrm{Cx} 43 \mathrm{HC}$ activity per se, by applying Gap26 in Cx30 KO slices, was sufficient to totally mimic the reduction in MC UP state amplitude observed in dKO MCs, a condition where both $\mathrm{HC}$ and gap junction channel functions are disrupted. However, although this result rules out the contribution of Cx43-mediated gap junctional communication, it does not exclude a potential role played by $\mathrm{Cx} 30$. Interestingly, deleting the $\mathrm{C} \times 30$ gene, a condition that abolishes both Cx30 gap junction channel and $\mathrm{HC}$ functions, has no impact on MC UP state amplitude, suggesting that $\mathrm{Cx} 30$ is not involved in the modulation of MC slow oscillations. Furthermore, although the two Cxs have a similar contribution to astroglial gap junctional communication in the OB (Roux et al., 2011), Cx43 deletion impacts MC behavior, whereas $\mathrm{Cx} 30$ deletion does not. Finally, although astrocytes are able to communicate through gap junction channels in the Cx43 KO (Roux et al., 2011), UP state reduction in MCs is similar to that in the $\mathrm{dKO}$, where astrocyte gap junctional communication is disrupted. Altogether, these observations indicate that gap junction channel function is not primarily involved in the modulation of MC UP states, as opposed to Cx43 HC function.

\section{Astrocyte-derived purines modulate slow network dynamics}

Our study indicates that the modulation exerted by $\mathrm{Cx} 43 \mathrm{HCs}$ requires functional adenosine A1 receptors. Indeed, like in other brain regions (Kang et al., 2008; Torres et al., 2012; Chever et al., 2014), astrocyte Cx43 HCs in the OB are responsible for ATP release. Previous data suggest that the conversion of ATP to adenosine is prominent in the $\mathrm{OB}$ compared to other brain regions (Langer et al., 2008). This feature suggests that adenosine plays a major role in the OB circuit function compared to ATP. Although we found that inhibiting $\mathrm{Cx} 43 \mathrm{HC}$ function reduces extracellular ATP levels, we cannot exclude that adenosine is directly released via $\mathrm{Cx} 43 \mathrm{HCs}$, or that activation of $\mathrm{Cx} 43 \mathrm{HCs}$ induces a chain of cellular events resulting in the release of ATP/ adenosine (Lovatt et al., 2012).

The importance of astrocyte-derived purines in the modulation of slow network rhythms has previously been highlighted in the neocortex, during sleep following sleep deprivation (Fellin et al., 2009; Halassa et al., 2009) or inflammatory stress (Nadjar et al., 2013), and in an ex vivo model of slow oscillations (Poskanzer and Yuste, 2011). Overall, these studies strongly suggest a role for astrocyte calcium-dependent vesicular release in the modulation of neocortical slow oscillations. Our study highlights an additional pathway that also involves astrocyte-derived purines, but relies on Cx43 HC-mediated gliotransmission and impacts slow oscillation amplitude: treatment with an $\mathrm{A} 1$ receptor antagonist reduces the amplitude of MC UP states per se, and blockade of Cx43 HCs has no effect when A1 receptors are inhibited. Altogether, these results indicate that although ATP/adenosine can also be released by neurons and other cell types (Brambilla et al., 2005; Lovatt et al., 2012; Lohr et al., 2014), astrocyte-derived adenosine is involved in slow oscillatory patterns in different neuronal circuits.

UP/DOWN states are driven by complex network interactions. Explaining the impact of adenosine receptors on such interactions by extrapolating the already known functions of adenosine receptors at the synaptic level is extremely difficult.
Nonetheless, since A1 is facilitating and A2 suppressing, one may hypothesize that the enhancement of UP states by adenosine is due to the facilitating A2 receptor activation or via the A1receptor mediated suppression of inhibitory interneuron function (disinhibition; Ulrich and Huguenard, 1995; Oliet and Poulain, 1999; Morairty et al., 2004). Our results indicate that A1-mediated disinhibition is most likely, although we cannot rule out a direct enhancement of the excitatory transmission by A1 receptor activation.

\section{Mechanisms of UP state generation in the olfactory bulb}

Two different mechanisms have been proposed to explain persistent activities and UP states in different brain areas, including the OB: one relies on intrinsic membrane properties (Heyward et al., 2001; Hayar et al., 2004b; Major and Tank, 2004), and the other involves self-sustained excitation mediated by recurrent activity and balanced by inhibition (Sanchez-Vives and McCormick, 2000; Shu et al., 2003). The OB circuit seems perfectly adapted to the second model: MCs associated with individual glomeruli form recurrent networks via dendrodendritic interactions and Cx36-based gap junctions (Isaacson, 1999; Schoppa and Westbrook, 2001; Urban and Sakmann, 2002; Christie et al., 2005; Christie and Westbrook, 2006), modulated by inhibitory inputs located in both the glomerular and the deeper layers (Lledo et al., 2005; Fukunaga et al., 2014). Our results argue in favor of a network-mediated mechanism, with a critical role for glomerular layer interactions: the frequency and amplitude of MC slow oscillations are not correlated with their membrane potential (Fig. $2 A, B)$, which rules out a role played by MC intrinsic membrane properties, and the blockade of glutamatergic transmission inhibits MC UP state generation (Fig. 2D). While these observations point toward a network-generated process, our data are also compatible with a combination of the two aforementioned models (i.e., single cell and network mechanisms). Indeed, tufted cells are able to drive the glomerular circuit (Hayar et al., 2004a; De Saint Jan et al., 2009), and unlike MCs, they show spontaneous depolarizations in the slow frequency range, dependent on intrinsic membrane properties (Hayar et al., 2004b). Tufted cells intrinsic properties could thus generate the oscillation that drives the MC recurrent network in the slow oscillatory mode.

\section{Intrinsic slow oscillations in olfactory bulb circuits: implications for sensory processing}

In vivo, $\mathrm{OB}$ slow oscillations are thought to mainly result from the phasic inputs related to the respiratory cycle (Macrides and Chorover, 1972; Cang and Isaacson, 2003). However, the persistence in the $\mathrm{OB}$ of slow oscillatory activities in acute slices (present study; Carlson et al., 2000; Puopolo and Belluzzi, 2001; Schoppa and Westbrook, 2001, 2002; Christie et al., 2005; Christie and Westbrook, 2006; De Saint Jan and Westbrook, 2007; De Saint Jan et al., 2009) or in vivo after tracheotomy (Ravel and Pager, 1990; Fontanini et al., 2003), pharmacological blockade of the sensory input (Stakic et al., 2011), or uncoupling from the respiratory cycle (Grosmaitre et al., 2007) suggests that slow rhythmic activity is also intrinsic to $\mathrm{OB}$ circuits. In vivo, such intrinsic slow oscillations are likely entrained by rhythmic external stimuli that exhibit overlapping frequencies (Schoppa and Westbrook, 2001; Hayar et al., 2004b). Along these lines, transitions from UP to DOWN states can be triggered by external auditory stimuli in the auditory cortex under anesthesia (Gao et al., 2009). Such a strategy ("synchronization of pulse-coupled biological oscillators"; Mirollo and Strogatz, 1990) is known to optimize energy costs for the generation of oscillatory activity (Buzsaki, 2006). 
In the $\mathrm{OB}$, we found that the reduced MC UP state amplitude in mice lacking both astroglial Cxs is associated with lower UP state firing rates compared to WT MCs. In vivo, the amplitude of the depolarization during UP states could play a critical role in controlling the gain of sensory responses (Castro-Alamancos, 2009): by bringing excitatory inputs closer to the firing threshold, UP states could increase the probability of olfactory sensory inputs to evoke a spike in the target MCs (but see Reig et al., 2015). Therefore, when astroglial Cx43 HCs are active, MC responses to weak stimuli may be facilitated, as well as the transmission of information to downstream areas.

Taken as a whole, this study shows that OB astrocytes, via activity-dependent $\mathrm{Cx} 43 \mathrm{HC}$ function, are able to modulate $\mathrm{MC}$ UP state amplitude. The bidirectional interaction between astrocytes and neuronal circuits described herein may be crucial in determining the gain of olfactory inputs and thus contribute to olfactory information processing.

\section{References}

Abudara V, Roux L, Dallérac G, Matias I, Dulong J, Mothet JP, Rouach N, Giaume C (2015) Activated microglia impairs neuroglial interaction by opening Cx43 hemichannels in hippocampal astrocytes. Glia 63:795-811. CrossRef Medline

Agulhon C, Fiacco TA, McCarthy KD (2010) Hippocampal short- and longterm plasticity are not modulated by astrocyte $\mathrm{Ca} 2+$ signaling. Science 327:1250-1254. CrossRef Medline

Amzica F, Massimini M, Manfridi A (2002) Spatial buffering during slow and paroxysmal sleep oscillations in cortical networks of glial cells in vivo. J Neurosci 22:1042-1053. Medline

Angulo MC, Kozlov AS, Charpak S, Audinat E (2004) Glutamate released from glial cells synchronizes neuronal activity in the hippocampus. J Neurosci 24:6920-6927. CrossRef Medline

Araque A, Carmignoto G, Haydon PG, Oliet SH, Robitaille R, Volterra A (2014) Gliotransmitters travel in time and space. Neuron 81:728-739. CrossRef Medline

Aroniadou-Anderjaska V, Ennis M, Shipley MT (1999a) Current-source density analysis in the rat olfactory bulb: laminar distribution of kainate/ AMPA- and NMDA-receptor-mediated currents. J Neurophysiol 81: 15-28. Medline

Aroniadou-Anderjaska V, Ennis M, Shipley MT (1999b) Dendrodendritic recurrent excitation in mitral cells of the rat olfactory bulb. J Neurophysiol 82:489-494. Medline

Bailey MS, Shipley MT (1993) Astrocyte subtypes in the rat olfactory bulb: morphological heterogeneity and differential laminar distribution. J Comp Neurol 328:501-526. CrossRef Medline

Barres BA (2008) The mystery and magic of glia: a perspective on their roles in health and disease. Neuron 60:430-440. CrossRef Medline

Bennett MV, Contreras JE, Bukauskas FF, Sáez JC (2003) New roles for astrocytes: gap junction hemichannels have something to communicate. Trends Neurosci 26:610-617. CrossRef Medline

Bergersen LH, Morland C, Ormel L, Rinholm JE, Larsson M, Wold JF, Røe AT, Stranna A, Santello M, Bouvier D, Ottersen OP, Volterra A, Gundersen V (2012) Immunogold detection of L-glutamate and D-serine in small synaptic-like microvesicles in adult hippocampal astrocytes. Cereb Cortex 22:1690-1697. CrossRef Medline

Bezzi P, Gundersen V, Galbete JL, Seifert G, Steinhäuser C, Pilati E, Volterra A (2004) Astrocytes contain a vesicular compartment that is competent for regulated exocytosis of glutamate. Nat Neurosci 7:613-620. CrossRef Medline

Brambilla D, Chapman D, Greene R (2005) Adenosine mediation of presynaptic feedback inhibition of glutamate release. Neuron 46:275-283. CrossRef Medline

Buzsaki G (2006) Rhythms of the brain. Oxford UP: New York.

Cang J, Isaacson JS (2003) In vivo whole-cell recording of odor-evoked synaptic transmission in the rat olfactory bulb. J Neurosci 23:4108-4116. Medline

Carlson GC, Shipley MT, Keller A (2000) Long-lasting depolarizations in mitral cells of the rat olfactory bulb. J Neurosci 20:2011-2021. Medline

Castro-Alamancos MA (2009) Cortical up and activated states: implications for sensory information processing. Neuroscientist 15:625-634. CrossRef Medline

Chauvette S, Volgushev M, Timofeev I (2010) Origin of active states in local neocortical networks during slow sleep oscillation. Cereb Cortex 20: 2660-2674. CrossRef Medline

Chaytor AT, Evans WH, Griffith TM (1997) Peptides homologous to extracellular loop motifs of connexin 43 reversibly abolish rhythmic contractile activity in rabbit arteries. J Physiol 503:99-110. CrossRef Medline

Chever O, Lee CY, Rouach N (2014) Astroglial connexin43 hemichannels tune Basal excitatory synaptic transmission. J Neurosci 34:11228-11232. CrossRef Medline

Chiu K, Greer CA (1996) Immunocytochemical analyses of astrocyte development in the olfactory bulb. Brain Res Dev Brain Res 95:28-37. CrossRef Medline

Christie JM, Westbrook GL (2006) Lateral excitation within the olfactory bulb. J Neurosci 26:2269-2277. CrossRef Medline

Christie JM, Bark C, Hormuzdi SG, Helbig I, Monyer H, Westbrook GL (2005) Connexin 36 mediates spike synchrony in olfactory bulb glomeruli. Neuron 46:761-772. CrossRef Medline

Contreras JE, Sáez JC, Bukauskas FF, Bennett MV (2003) Gating and regulation of connexin $43(\mathrm{Cx} 43)$ hemichannels. Proc Natl Acad Sci U S A 100:11388-11393. CrossRef Medline

Cotrina ML, Lin JH, Alves-Rodrigues A, Liu S, Li J, Azmi-Ghadimi H, Kang J, Naus CC, Nedergaard M (1998) Connexins regulate calcium signaling by controlling ATP release. Proc Natl Acad Sci U S A 95:15735-15740. CrossRef Medline

Crochet S, Petersen CC (2006) Correlating whisker behavior with membrane potential in barrel cortex of awake mice. Nat Neurosci 9:608-610. CrossRef Medline

Crunelli V, Hughes SW (2010) The slow $(<1 \mathrm{~Hz})$ rhythm of non-REM sleep: a dialogue between three cardinal oscillators. Nat Neurosci 13: 9-17. CrossRef Medline

Cunha RA (2001) Adenosine as a neuromodulator and as a homeostatic regulator in the nervous system: different roles, different sources and different receptors. Neurochem Int 38:107-125. CrossRef Medline

De Saint Jan D, Westbrook GL (2005) Detecting activity in olfactory bulb glomeruli with astrocyte recording. J Neurosci 25:2917-2924. CrossRef Medline

De Saint Jan D, Westbrook GL (2007) Disynaptic amplification of metabotropic glutamate receptor 1 responses in the olfactory bulb. J Neurosci 27:132-140. CrossRef Medline

De Saint Jan D, Hirnet D, Westbrook GL, Charpak S (2009) External tufted cells drive the output of olfactory bulb glomeruli. J Neurosci 29:20432052. CrossRef Medline

Desplantez T, Verma V, Leybaert L, Evans WH, Weingart R (2012) Gap26, a connexin mimetic peptide, inhibits currents carried by connexin 43 hemichannels and gap junction channels. Pharmacol Res 65:546-552. CrossRef Medline

Didier A, Carleton A, Bjaalie JG, Vincent JD, Ottersen OP, Storm-Mathisen J, Lledo PM (2001) A dendrodendritic reciprocal synapse provides a recurrent excitatory connection in the olfactory bulb. Proc Natl Acad Sci U S A 98:6441-6446. CrossRef Medline

Dixon AK, Gubitz AK, Sirinathsinghji DJ, Richardson PJ, Freeman TC (1996) Tissue distribution of adenosine receptor mRNAs in the rat. Br J Pharmacol 118:1461-1468. CrossRef Medline

Dunwiddie TV, Diao L, Proctor WR (1997) Adenine nucleotides undergo rapid, quantitative conversion to adenosine in the extracellular space in rat hippocampus. J Neurosci 17:7673-7682. Medline

Fellin T, Halassa MM, Terunuma M, Succol F, Takano H, Frank M, Moss SJ, Haydon PG (2009) Endogenous nonneuronal modulators of synaptic transmission control cortical slow oscillations in vivo. Proc Natl Acad Sci U S A 106:15037-15042. CrossRef Medline

Fiacco TA, Agulhon C, Taves SR, Petravicz J, Casper KB, Dong X, Chen J, McCarthy KD (2007) Selective stimulation of astrocyte calcium in situ does not affect neuronal excitatory synaptic activity. Neuron 54:611-626. CrossRef Medline

Fontanini A, Spano P, Bower JM (2003) Ketamine-xylazine-induced slow $(<1.5 \mathrm{~Hz})$ oscillations in the rat piriform (olfactory) cortex are functionally correlated with respiration. J Neurosci 23:7993-8001. Medline

Fujita T, Chen MJ, Li B, Smith NA, Peng W, Sun W, Toner MJ, Kress BT, Wang L, Benraiss A, Takano T, Wang S, Nedergaard M (2014) Neuronal 
transgene expression in dominant-negative SNARE mice. J Neurosci 34: 16594-16604. CrossRef Medline

Fukunaga I, Herb JT, Kollo M, Boyden ES, Schaefer AT (2014) Independent control of gamma and theta activity by distinct interneuron networks in the olfactory bulb. Nat Neurosci 17:1208-1216. CrossRef Medline

Gao L, Meng X, Ye C, Zhang H, Liu C, Dan Y, Poo MM, He J, Zhang X (2009) Entrainment of slow oscillations of auditory thalamic neurons by repetitive sound stimuli. J Neurosci 29:6013-6021. CrossRef Medline

Giaume C, Theis M (2010) Pharmacological and genetic approaches to study connexin-mediated channels in glial cells of the central nervous system. Brain Res Rev 63:160-176. CrossRef Medline

Giaume C, Koulakoff A, Roux L, Holcman D, Rouach N (2010) Astroglial networks: a step further in neuroglial and gliovascular interactions. Nat Rev Neurosci 11:87-99. CrossRef Medline

Giaume C, Orellana JA, Abudara V, Sáez JC (2012) Connexin-based channels in astrocytes: how to study their properties. Methods Mol Biol 814: 283-303. CrossRef Medline

Giaume C, Leybaert L, Naus CC, Sáez JC (2013) Connexin and pannexin hemichannels in brain glial cells: properties, pharmacology, and roles. Front Pharmacol 4:88. Medline

Grosmaitre X, Santarelli LC, Tan J, Luo M, Ma M (2007) Dual functions of mammalian olfactory sensory neurons as odor detectors and mechanical sensors. Nat Neurosci 10:348-354. CrossRef Medline

Gurden H, Uchida N, Mainen ZF (2006) Sensory-evoked intrinsic optical signals in the olfactory bulb are coupled to glutamate release and uptake. Neuron 52:335-345. CrossRef Medline

Halassa MM, Florian C, Fellin T, Munoz JR, Lee SY, Abel T, Haydon PG, Frank MG (2009) Astrocytic modulation of sleep homeostasis and cognitive consequences of sleep loss. Neuron 61:213-219. CrossRef Medline

Hamilton NB, Attwell D (2010) Do astrocytes really exocytose neurotransmitters? Nat Rev Neurosci 11:227-238. CrossRef Medline

Hayar A, Karnup S, Ennis M, Shipley MT (2004a) External tufted cells: a major excitatory element that coordinates glomerular activity. J Neurosci 24:6676-6685. CrossRef Medline

Hayar A, Karnup S, Shipley MT, Ennis M (2004b) Olfactory bulb glomeruli: external tufted cells intrinsically burst at theta frequency and are entrained by patterned olfactory input. J Neurosci 24:1190-1199. CrossRef Medline

Heyward P, Ennis M, Keller A, Shipley MT (2001) Membrane bistability in olfactory bulb mitral cells. J Neurosci 21:5311-5320. Medline

Iglesias R, Dahl G, Qiu F, Spray DC, Scemes E (2009) Pannexin 1: the molecular substrate of astrocyte "hemichannels." J Neurosci 29:7092-7097. CrossRef

Isaacson JS (1999) Glutamate spillover mediates excitatory transmission in the rat olfactory bulb. Neuron 23:377-384. CrossRef Medline

Jourdain P, Bergersen LH, Bhaukaurally K, Bezzi P, Santello M, Domercq M, Matute C, Tonello F, Gundersen V, Volterra A (2007) Glutamate exocytosis from astrocytes controls synaptic strength. Nat Neurosci 10: 331-339. CrossRef Medline

Kaelin-Lang A, Lauterburg T, Burgunder JM (1999) Expression of adenosine A2a receptors gene in the olfactory bulb and spinal cord of rat and mouse. Neurosci Lett 261:189-191. CrossRef Medline

Kang J, Kang N, Lovatt D, Torres A, Zhao Z, Lin J, Nedergaard M (2008) Connexin 43 hemichannels are permeable to ATP. J Neurosci 28:47024711. CrossRef Medline

Karnup SV, Hayar A, Shipley MT, Kurnikova MG (2006) Spontaneous field potentials in the glomeruli of the olfactory bulb: the leading role of juxtaglomerular cells. Neuroscience 142:203-221. CrossRef Medline

Langer D, Hammer K, Koszalka P, Schrader J, Robson S, Zimmermann H (2008) Distribution of ectonucleotidases in the rodent brain revisited. Cell Tissue Res 334:199-217. CrossRef Medline

Lee HS, Ghetti A, Pinto-Duarte A, Wang X, Dziewczapolski G, Galimi F, Huitron-Resendiz S, Piña-Crespo JC, Roberts AJ, Verma IM, Sejnowski TJ, Heinemann SF (2014) Astrocytes contribute to gamma oscillations and recognition memory. Proc Natl Acad Sci U S A 111:E3343-E3352. CrossRef Medline

Li D, Hérault K, Silm K, Evrard A, Wojcik S, Oheim M, Herzog E, Ropert N (2013) Lack of evidence for vesicular glutamate transporter expression in mouse astrocytes. J Neurosci 33:4434-4455. CrossRef Medline

Lledo PM, Gheusi G, Vincent JD (2005) Information processing in the mammalian olfactory system. Physiol Rev 85:281-317. CrossRef Medline

Lohr C, Grosche A, Reichenbach A, Hirnet D (2014) Purinergic neuron-glia interactions in sensory systems. Pflugers Arch 466:1859-1872. CrossRef Medline

Lovatt D, Xu Q, Liu W, Takano T, Smith NA, Schnermann J, Tieu K, Nedergaard M (2012) Neuronal adenosine release, and not astrocytic ATP release, mediates feedback inhibition of excitatory activity. Proc Natl Acad Sci U S A 109:6265-6270. CrossRef Medline

Lutz SE, Zhao Y, Gulinello M, Lee SC, Raine CS, Brosnan CF (2009) Deletion of astrocyte connexins 43 and 30 leads to a dysmyelinating phenotype and hippocampal CA1 vacuolation. J Neurosci 29:7743-7752. CrossRef Medline

Macrides F, Chorover SL (1972) Olfactory bulb units: activity correlated with inhalation cycles and odor quality. Science 175:84-87. CrossRef Medline

Major G, Tank D (2004) Persistent neural activity: prevalence and mechanisms. Curr Opin Neurobiol 14:675-684. CrossRef Medline

Mirollo RE, Strogatz SH (1990) Synchronization of pulse-coupled biological oscillators. SIAM J Appl Math 50:1645-1662. CrossRef

Morairty S, Rainnie D, McCarley R, Greene R (2004) Disinhibition of ventrolateral preoptic area sleep-active neurons by adenosine: a new mechanism for sleep promotion. Neuroscience 123:451-457. CrossRef Medline

Nadjar A, Blutstein T, Aubert A, Laye S, Haydon PG (2013) Astrocytederived adenosine modulates increased sleep pressure during inflammatory response. Glia 61:724-731. CrossRef Medline

Nedergaard M, Verkhratsky A (2012) Artifact versus reality-how astrocytes contribute to synaptic events. Glia 60:1013-1023. CrossRef Medline

Oliet SH, Poulain DA (1999) Adenosine-induced presynaptic inhibition of IPSCs and EPSCs in rat hypothalamic supraoptic nucleus neurones. J Physiol 520:815-825. CrossRef Medline

Orellana JA, Sáez PJ, Shoji KF, Schalper KA, Palacios-Prado N, Velarde V, Giaume C, Bennett MV, Sáez JC (2009) Modulation of brain hemichannels and gap junction channels by pro-inflammatory agents and their possible role in neurodegeneration. Antioxid Redox Signal 11:369-399. CrossRef Medline

Pannasch U, Vargová L, Reingruber J, Ezan P, Holcman D, Giaume C, SykováE, Rouach N (2011) Astroglial networks scale synaptic activity and plasticity. Proc Natl Acad Sci U S A 108:8467-8472. CrossRef Medline

Pannasch U, Freche D, Dallérac G, Ghézali G, Escartin C, Ezan P, CohenSalmon M, Benchenane K, Abudara V, Dufour A, Lübke JH, Déglon N Knott G, Holcman D, Rouach N (2014) Connexin 30 sets synaptic strength by controlling astroglial synapse invasion. Nat Neurosci 17: 549-558. CrossRef Medline

Pascual O, Casper KB, Kubera C, Zhang J, Revilla-Sanchez R, Sul JY, Takano H, Moss SJ, McCarthy K, Haydon PG (2005) Astrocytic purinergic signaling coordinates synaptic networks. Science 310:113-116. CrossRef Medline

Pellerin L, Magistretti PJ (2012) Sweet sixteen for ANLS. J Cereb Blood Flow Metab 32:1152-1166. CrossRef Medline

Petravicz J, Fiacco TA, McCarthy KD (2008) Loss of IP3 receptordependent $\mathrm{Ca} 2+$ increases in hippocampal astrocytes does not affect baseline CA1 pyramidal neuron synaptic activity. J Neurosci 28:49674973. CrossRef Medline

Pimentel DO, Margrie TW (2008) Glutamatergic transmission and plasticity between olfactory bulb mitral cells. J Physiol 586:2107-2119. CrossRef Medline

Poskanzer KE, Yuste R (2011) Astrocytic regulation of cortical UP states. Proc Natl Acad Sci U S A 108:18453-18458. CrossRef Medline

Puopolo M, Belluzzi O (2001) NMDA-dependent, network-driven oscillatory activity induced by bicuculline or removal of $\mathrm{Mg} 2+$ in rat olfactory bulb neurons. Eur J Neurosci 13:92-102. CrossRef Medline

Ravel N, Pager J (1990) Respiratory patterning of the rat olfactory bulb unit activity: nasal versus tracheal breathing. Neurosci Lett 115:213-218. CrossRef Medline

Reig R, Zerlaut Y, Vergara R, Destexhe A, Sanchez-Vives MV (2015) Gain modulation of synaptic inputs by network state in auditory cortex in vivo. J Neurosci 35:2689-2702. CrossRef Medline

Retamal MA, Froger N, Palacios-Prado N, Ezan P, Sáez PJ, Sáez JC, Giaume C (2007) Cx43 hemichannels and gap junction channels in astrocytes are regulated oppositely by proinflammatory cytokines released from activated microglia. J Neurosci 27:13781-13792. CrossRef Medline

Rouach N, Koulakoff A, Abudara V, Willecke K, Giaume C (2008) Astroglial metabolic networks sustain hippocampal synaptic transmission. Science 322:1551-1555. CrossRef Medline 
Roux L, Benchenane K, Rothstein JD, Bonvento G, Giaume C (2011) Plasticity of astroglial networks in olfactory glomeruli. Proc Natl Acad Sci U S A 108:18442-18446. CrossRef Medline

Salin PA, Lledo PM, Vincent JD, Charpak S (2001) Dendritic glutamate autoreceptors modulate signal processing in rat mitral cells. J Neurophysiol 85:1275-1282. Medline

Sanchez-Vives MV, McCormick DA (2000) Cellular and network mechanisms of rhythmic recurrent activity in neocortex. Nat Neurosci 3:10271034. CrossRef Medline

Schoppa NE, Westbrook GL (2001) Glomerulus-specific synchronization of mitral cells in the olfactory bulb. Neuron 31:639-651. CrossRef Medline

Schoppa NE, Westbrook GL (2002) AMPA autoreceptors drive correlated spiking in olfactory bulb glomeruli. Nat Neurosci 5:1194-1202. CrossRef Medline

Seamari Y, Narváez JA, Vico FJ, Lobo D, Sanchez-Vives MV (2007) Robust off- and online separation of intracellularly recorded up and down cortical states. PLoS One 2:e888. CrossRef Medline

Shu Y, Hasenstaub A, McCormick DA (2003) Turning on and off recurrent balanced cortical activity. Nature 423:288-293. CrossRef Medline

Sirota A, Buzsáki G (2005) Interaction between neocortical and hippocampal networks via slow oscillations. Thalamus Relat Syst 3:245-259. CrossRef Medline

Stakic J, Suchanek JM, Ziegler GP, Griff ER (2011) The source of spontaneous activity in the main olfactory bulb of the rat. PLoS One 6:e23990. CrossRef Medline

Stehberg J, Moraga-Amaro R, Salazar C, Becerra A, Echeverría C, Orellana JA, Bultynck G, Ponsaerts R, Leybaert L, Simon F, Sáez JC, Retamal MA (2012) Release of gliotransmitters through astroglial connexin 43 hemichannels is necessary for fear memory consolidation in the basolateral amygdala. FASEB J 26:3649-3657. CrossRef Medline

Steriade M, Nuñez A, Amzica F (1993) A novel slow (<1 Hz) oscillation of neocortical neurons in vivo: depolarizing and hyperpolarizing components. J Neurosci 13:3252-3265. Medline

Teubner B, Michel V, Pesch J, Lautermann J, Cohen-Salmon M, Söhl G, Jahnke K, Winterhager E, Herberhold C, Hardelin JP, Petit C, Willecke K (2003) Connexin30 (Gjb6)-deficiency causes severe hearing impairment and lack of endocochlear potential. Hum Mol Genet 12:13-21. CrossRef Medline

Theis M, Jauch R, Zhuo L, Speidel D, Wallraff A, Döring B, Frisch C, Söhl G, Teubner B, Euwens C, Huston J, Steinhäuser C, Messing A, Heinemann U, Willecke K (2003) Accelerated hippocampal spreading depression and enhanced locomotory activity in mice with astrocyte-directed inactivation of connexin43. J Neurosci 23:766-776. Medline

Timofeev I, Grenier F, Bazhenov M, Sejnowski TJ, Steriade M (2000) Origin of slow cortical oscillations in deafferented cortical slabs. Cereb Cortex 10:1185-1199. CrossRef Medline

Torres A, Wang F, Xu Q, Fujita T, Dobrowolski R, Willecke K, Takano T, Nedergaard M (2012) Extracellular $\mathrm{Ca}(2)(+)$ acts as a mediator of communication from neurons to glia. Sci Signal 5:ra8. Medline

Ulrich D, Huguenard JR (1995) Purinergic inhibition of GABA and glutamate release in the thalamus: implications for thalamic network activity. Neuron 15:909-918. CrossRef Medline

Urban NN, Sakmann B (2002) Reciprocal intraglomerular excitation and intra- and interglomerular lateral inhibition between mouse olfactory bulb mitral cells. J Physiol 542:355-367. CrossRef Medline

Wallraff A, Köhling R, Heinemann U, Theis M, Willecke K, Steinhäuser C (2006) The impact of astrocytic gap junctional coupling on potassium buffering in the hippocampus. J Neurosci 26:5438-5447. CrossRef Medline

Wang N, De Bock M, Antoons G, Gadicherla AK, Bol M, Decrock E, Evans WH, Sipido KR, Bukauskas FF, Leybaert L (2012) Connexin mimetic peptides inhibit $\mathrm{Cx} 43$ hemichannel opening triggered by voltage and intracellular Ca2 + elevation. Basic Res Cardiol 107:304. CrossRef Medline 